\title{
The Property-Tax Bundle of Rights
}

\author{
Edward J. McCaffery ${ }^{1}$
}

Concept and Conceptions $\quad 5$

The Road Ahead 9

$\begin{array}{lr}\text { 2. Elements } & 10\end{array}$

$\begin{array}{ll}\text { The Rights of Property } & 10\end{array}$

The Term Structure of Property 12

Two Components of Tax 14

The Timing of Tax 15

The Rate Structure of Tax 16

Two Forms of Savings Accounts 17

Two Conditions of Equivalence 18

The Project of a Property-Tax Bundle 20

Money as Property 22

Money in Locke $\quad 25$

Missing a Point 30

3. The Absolute Property-Tax Bundle

Property Concepts 33

Tax Concepts $\quad 35$

${ }^{1}$ Robert C. Packard Trustee Chair in Law, Economics \& Political Science, University of Southern California (B.A., Yale (Classics \& Philosophy); JD, Harvard; MA (Economics), University of Southern California.) This Article grows out of a book-length manuscript, A New Understanding of Property: The Case Against Waste (manuscript on file with author.). I thank here the many people with whom I have had conversations about that manuscript, and regarding a unified concept of property and tax, over many years: Bruce Ackerman, Greg Alexander, Anne Alstott, Scott Altman, Jennifer Arlen, Reuven Avi-Yonah, Guido Calabresi, Alex Capron, Marshall Cohen, Robert Cooter, David Dolinko, Richard Epstein, Jesse Fried, Ron Garet, Tom Griffith, Michael Heller, Phil Hoffman, Dan Klerman, George Lefcoe, Saul Levmore, Bentley MacLeod, Daniel Markovits, Frank Michelman, Steven Munzer, Avner Offer, Jonathan Schwartz, Seanna Shiffrin, Henry Smith, Larry Simon, Nomi Stoltzenberg, Chris Stone, Jeff Strnad, Eric Talley, Roberto Mangabeira Unger, Mark Weinstein, and James Q. Whitman. I owe additional thanks to Greg Keating and to the late William D. Andrews for their especially detailed commentaries on earlier versions of the book manuscript. I thank Vivian Liu and David Sorenson for research assistance, along with the wonderful reference librarians at USC Gould ool of Law.. Finally, I give a special note of thanks and commemoration to my now late colleague Ed Kleinbard, with whom I shared passions for tax, social justice, and the writings of Adam Smith. Footnotes remain incomplete in this version. 
Money Escapes the Income Tax $\quad 37$

Rothification 38

The Monetization Moment of Tax 39

Money Escapes the Estate Tax 41

Money Escapes the Generation-Skipping Tax (the Birth of Dynasty Trusts) 43

Money Escapes the Rule Against Perpetuities $\quad 45$

What Butchers, Brewers, and Bakers Bequest $\quad 47$

Three Paths for Money, Two Types of Trusts 48

The Illustrative Case of Howard Hughes

Money under the Absolute Property-Tax Bundle: Cash as King 53

Mayor Bloomberg and The Paradox of Death Taxation 54

4. A Fiduciary Property-Tax Bundle $\quad 58$

$\begin{array}{ll}\text { Property Concepts } & 58\end{array}$

The Usufruct

$\begin{array}{ll}\text { The Life Estate } & 62\end{array}$

Capital as Remainder $\quad 64$

The Battle of Co-Owners: Doctrines of Waste 65

$\begin{array}{ll}\text { Tax Concepts } & 68\end{array}$

A Simple Source Neutrality $\quad 69$

$\begin{array}{ll}\text { Changing the Rate Structure } & 70\end{array}$

Connecting the Timing and Rate Structure of Tax $\quad 72$

A Social Spendthrift Trust $\quad 73$

$\begin{array}{ll}\text { Capital for the Ordinary Citizen } & 75\end{array}$

Capital for the Aristocrat $\quad 77$

$\begin{array}{ll}\text { Capital for the Plutocrat } & 79\end{array}$

From the Sovereign's Side $\quad 80$

Money under the Fiduciary Property-Tax Bundle: Cash, Constrained $\quad 81$

Revisiting Mayor Bloomberg 81

5. Reimagining Property $\quad 84$

$\begin{array}{ll}\text { A Twentieth Century Conversation } & 85\end{array}$

Back to the Beginning: Capital and Labor Strike a Deal 88

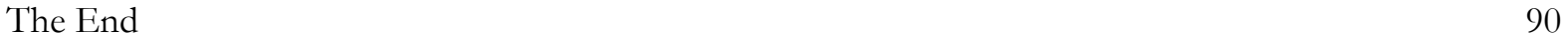




\section{Connections}

Man is born free, and he is everywhere in chains.

Jean-Jacque Rousseau, The Social Contract, Book 1, Chapter 1

We are born free but think everywhere in silos of our own construction.

Consider property and tax, distant cousins in the law school curriculum. Property is a core subject, typically required in the first year of study and tested on the multistate bar exam, a domain of centuries-old common law cases about animal carcassses and lost-and-found things; easements, covenants and servitudes; and increasingly archaic doctrines such as the Rule against Perpetuities. ${ }^{2}$ Tax is an elective, advanced, business-law subject about money, featuring detailed discussions of dizzying federal statutes, regulations, and math. Yet property and tax are in fact simply two sides of the same coin, the coin being the ownership of society's material resources. Tax marks the boundary between what is private and what is public. Like all boundaries, it both separates and connects its adjacent parts, delimiting what each means.

Property and tax are inextricably analytically bound. Legal scholars in the Anglo-American liberal Enlightenment tradition refer to "property" as a bundle of rights -- a set of powers that a property owner has, subject to various limitations. ${ }^{3}$ Yet there is no such thing as a "property bundle of rights" independent of tax, which represents one's obligations to the body politic. There is no tax without property, or something of economic value to tax. Nor is there any property without tax: there is no legal concept of "property" independent of laws, and no laws without society, and no

\footnotetext{
${ }^{2}$ For an illustrative and readable guide to Property as typically taught in the first year of American law schools, see THOMAS W. MERRILL AND HENRY E. SMITH, THE OXFORD INTRODUCTIONS TO U.S. LAW: PROPERTY, 1ST EDITION (2010).

${ }^{3}$ See e.g. J.E. Penner, The "Bundle of Rights” Picture of Property, 43 UCLA Law Review 711 (1996).
} 
society without at least the inchoate power to tax or otherwise command exclusive power over society's material resources. ${ }^{4}$ Even a decision not to tax, after all, is a decision to allow property to remain exclusively private. Any property bundle of rights is necessarily a property-tax bundle of rights.

We do not generally think this way. We do not systematically integrate ideas of property and tax into a unified understanding of a property-tax bundle of rights. We have paid and are paying a price for this intellectual failure. America has settled into an absolute conception of the property-tax bundle by default. Property law gives a present owner absolute powers. Tax laws levy an initial charge on labor inputs and then step aside. ${ }^{5}$ Money falls through the cracks between disciplines: neither property nor tax regulate the use of private capital, fungible wealth. While absolute property rights over specific assets lead to the optimal use of such assets, and thus self and social interests tend to converge, the private use of money raises prospects for divergence and disharmony. Billionaires now abound. Their powers to use the wealth they control are absolute. Our continued dependence on their benevolence and restraint comes at grave costs and poses graver risks for a reasonable democratic society.

History has shown that absolute powers end poorly. The program of Adam Smith and Ronald Coase, to let absolute private property rights lead to maximal social wealth, is at risk of turning on itself as private capital runs free of all constraint. This Article shows how to reset the property-tax bundle of rights to rein in the power of private wealth. It offers the fiduciary

\footnotetext{
${ }^{4}$ Consider Charles Tilly's theory of the "extraction" of capital and its role in state building. CHARLES TILLY, . COERCION, CAPITAL AND EUROPEAN STATES: AD 990-1992 (1992); THE FORMATION OF NATIONAL STATES IN WESTERN EUROPE, (1975).

${ }^{5}$ See Edward J. McCaffery, The Death of the Income Tax (or, The Rise of America's Universal Wage Tax, 95 Ind. L. J. $1233(2020)$.
} 
conception, a reimagined property-tax bundle that generalizes an insight commonly sourced to Thomas Jefferson: It provides that society' wealth, capital itself, be held in usufruct for the living. Capital is made into a common pool, and the wealthiest are not allowed to use their wealth on their own personal pleasures. The rich become fiduciaries for all by operation of law, not from reliance on their benevolence alone.

\section{Concept and Conceptions}

The Article's primary task is analytic and jurisprudential, in the tradition of William Blackstone. ${ }^{6}$ It explains the concept of a property-tax bundle and then offers two conceptions of one, to point to choices available to a reasonable society. ${ }^{7}$ We see that how we think about things affects how we conceive of regulating them. Conceptions affect reality and reality affects conceptions. $^{8}$

All societies offer a property-tax bundle of rights. This is the concept. Both private individuals and the state share social wealth. The question is how. While the wider political culture tends to obsess over quantitative questions regarding the magnitude of taxes, the property-tax

\footnotetext{
${ }^{6}$ WILLIAM BLACKSTONE, COMMENTARIES ON THE LAWS OF ENGLAND. FACSIMILE EDITION. 4 VOLS. Chicago: University of Chicago Press (1766).

7 For the concept-conception distinction, see W.B. Galle, Essentially Contested Concepts, 56 Proceedings of the Aristotelian Society 167 (1955 - 1956). See also RONALD DWORKIN, LAW'S EMPIRE (1986).

${ }^{8}$ For other conceptions of property and for consideration of how our language and rhetoric shapes the realities of property, see for example Carol M. Rose, Canons of Property Talk, or Blackstone's Anxiety, Yale L.J. 108 (1998); CAROL M. ROSE, PROPERTY AND PERSUASION: ESSAYS ON THE HISTORY, THEORY, AND RHETORIC OF OWNERSHIP.( 1994); MARGARET JANE. REINTERPRETING PROPERTY (1993); GREGORY S. ALEXANDER, COMMODITY AND PROPRIETY: COMPETING VISIONS OF PROPERTY IN AMERICAN LEGAL THOUGHT (1998); LAURA S. UNDERKUFFLER, THE IDEA OF PROPERTY: ITS MEANING AND POWER (2003)..
} 
bundle asks qualitative questions about what "private ownership" means in a world with particular taxes in place. What rights do individuals have under different property-tax bundles?

America was born into the absolute conception. Smith taught us to let people be people; to set the rules of society so as to align the private incentives of butchers, brewers, and bakers in harmony with the public good. ${ }^{9}$ Blackstone suggested and then Coase later demonstrated that strong private property rights give citizens proper incentives to make the social equate with the private by internalizing the costs and benefits of property to an individual owner. ${ }^{10}$ Private property solves the "problem" of social costs by equating the private and social. Harold Demsetz extended this idea through time to make clear that finite mortals would optimally manage assets they owned through infinite time. Absolute private property rights lead to the maximal wealth of a nation. ${ }^{11}$ The state through its taxing powers need only sit back and take a share of the greater wealth produced by private individuals holding private property, like Tom Sawyer getting his friends to whitewash his fence. $^{12}$ At its root this is a moral conception of property: the institution serves the public good. ${ }^{13}$

This absolute conception of property has led seemingly naturally to a tax system that falls in the first instance on wages, as value is being added to the social pie, and never again. Private capital

9 ADAM SMITH, THE WEALTH OF NATIONS. (Collier, 1902) (1776).

10 Ronald H. Coase, The Problem of Social Cost, 3 Journal of Law \& Economics 1 (1960).

11 Harold Demsetz, Toward a Theory of Property Rights, 57 Am. Econ. Rev., Papers and Proceedings 347 (1967).

12 On Tom Sawyer, see MARK TWAIN, THE ADVENTURES OF TOM SAWYER, Chapter Two (where, after getting several friends to pay him to do the work to which he had been consigned as a punishment, Tom "had had a nice, good, idle time all the while_plenty of company —and the fence had three coats of whitewash on it! If he hadn't run out of whitewash he would have bankrupted every boy in the village.") Note that it does not matter how the state taxes, or extracts, to have the state have a direct interest in the nation's wealth. A modest sales or excise tax, such as existed in Smith's time, generates more revenue to the state where there is more economic activity to be taxed. America's dependence on labor taxes makes the government dependent on private sector jobs, partially explaining America's "welfare to workfare" movement. See JENNIFER MITTELSTADT, FROM WELFARE TO WORKFARE: THE UNINTENDED CONSEQUENCES OF LIBERAL REFORM, 1945-1965 (2005).

${ }^{13}$ See Thomas W. Merrill and Henry E. Smith. The Morality of Property, William \& Mary Law Rev. 1849 (2007). 
is held absolutely following the payment of an initial labor tax. Liam Murphy and Thoms Nagel see this understanding of ownership as "mythical," for it generates a strong sense of private entitlement to what is a joint social-product, wealth. ${ }^{14}$ But the understanding has real effects: it maps up with the now canonical rights and term structure of property. The rhetorical aspects of the absolute conception have been useful to a state that wants to motivate its butchers, brewers, and bakers to produce wealth for it, the state, to tax. Yet these same rhetorical aspects have also inculcated attitudes (“don't tread on me!") that have turned against the very state that set them forth. Over time the myth of ownership has made itself real vis a vis the money in one's pocket. Private capital has successfully fought off the imposition of any further tax or regulation on its use. Once one has money, after taxes, she can use it however she wants for all of time.

This absolute conception of the property-tax bundle is so rooted in American "common sense," as Clifford Geertz might say, ${ }^{15}$ or in the "everyday libertarianism" that Murphy and Nagel see as a prevalent daily worldview in America, that the conception can seem indistinguishable from the concept, as if "property" must mean absolute private property. This is a false necessity. Other conceptions of the property-tax bundle are readily imaginable and practicable.

The Article sets forth a fiduciary property-tax bundle. The central idea of the fiduciary conception is that those citizens who hold stores of property beyond their immediate daily needs and reasonable wants -- a small percent of any society, the top one percent or so -- have a responsibility to manage their excess capital for the good of all. By the time the butchers, brewers, and bakers have reached the level of billionaires, their wealth becomes primarily society's wealth,

\footnotetext{
${ }^{14}$ LIAM MURPHY AND THOMAS NAGEL. THE MYTH OF OWNERSHIP: TAXES AND JUSTICE. (2002).

${ }^{15}$ Clifford Geertz, Commons Sense as a Cultural System, 33 The Antioch Review 5 (Spring, 1975).
} 
which private individuals hold in usufruct. Like Murphy and Nagel and others, the revised understanding accepts that capital, or wealth, is a joint social product. But unlike as under the absolute property-tax bundle, the fiduciary bundle postpones the moment of demarcation until the private individual moves to use "her" wealth on private wants. In so doing, the fiduciary conception makes real -- makes a matter of the positive law -- the metaphor of a "common pool" of social capital, sourced back at least as far as Thomas Hobbes' Leviathan, ${ }^{16}$ given good form in John Rawls' A Theory of Justice,. ${ }^{17}$ and endorsed by the contemporary progressive legal scholar Roberto Mangabeira Unger. ${ }^{18}$ A simple analytic change to tax, to shift the moment of taxation from the time of inputs into a household to the time of outputs from the household, effects this radical change in the property-tax bundle. We can in fact see a fiduciary property-tax bundle of rights in inchoate form today under our tax system.

In many ways the alternative conception is prior to the absolute one. We see its roots in feudal times, before Blackstone and his understanding of property as a "sole and despotic dominion." ${ }^{19}$ Just as the feudal tenant held and managed his lands for a life estate term and at the pleasure of the King, who in effect held a reversion, wealthy individuals under the fiduciary conception hold their capital in trust, or usufruct, to serve the reasonable interests of the wider society. The usufruct was still a prevalent intellectual construct as of the time of John Locke, to be

16 THOMAS. HOBBES, LEVIATHAN, ( New York: Penguin Classics, 1985) (1651). Alvin Warren has pointed out that the ":common pool" language generally attributed to Hobbes is actually used by other commentators such as CHARLES FRIED, RIGHT AND WRONG (1978); NICHOLAS KALDOR, AN EXPENDITURE TAX (1955) at 53. Alvin Warren, Would a Consumption Tax Be Fairer Than an Income Tax?, 89 Yale. L.J. 1081, 1094 n.39 (1980). Warren himself had previously argued against the Hobbesean formulation. Alvin Warren, Fairness and a Consumption-Type or Cash Flow Personal Income Tax, 88 Harv.. L. Rev. (1975) at 933. ${ }^{17}$ JOHN RAWLS, A THEORY OF JUSTICE (1971).

${ }^{18}$ ROBERTO MANGABIERA UNGER. WHAT SHOULD LEGAL ANALYSIS BECOME?. (1996) at 139.

${ }^{19}$ See generally MARC.BLOCH, FEUDAL SOCIETY. VOL. 1. (1961). 
set aside by Blackstone and forgotten in contemporary times. This fiduciary property-tax bundle changes the nature of a property owner's bundle of rights back to a usufructure. It constrains the owner's previously absolute right to use "her" wealth however she wants by taking away her right to waste it. It gives society a tool for monitoring the spending of plutocrats that our common law theories have thus far left us lacking.

\section{The Road Ahead}

This Article proceeds in Section 2 to explain and add content to the elements in any conception of a property-tax bundle of rights. Sections 3 and 4 then compare and contrast an absolute with a fiduciary property-tax bundle. Section 5 concludes with a plea for reimagining property, and tax, and property and tax together.

Although its immediate purpose is analytic and descriptive, the ultimate aim of the Article is normative. It is proposing a rethinking of our property-tax bundle of rights. The absolute property-tax bundle no longer best serves the reasonable needs of American society, on account of its twin tendencies to allow individuals to amass large accumulations of capital built up tax-free over generations, and to be able to spend these massive sums without constraint or regard for others or for the future. Changing tax changes property. A fiduciary property-tax bundle reigns in the powers of billionaires in the present and protects the interests of the future. It prevents our wealthiest citizens from becoming enemies of the state by ensuring that they act as fiduciaries for it. We see all this through an exploration of two competing conceptions of the property-tax bundle. 


\section{Elements}

It is not from the benevolence of the butcher, the brewer, or the baker that we expect our dinner, but from their regard to their own self-interest. We address ourselves not to their humanity but to their self-love, and never talk to them of our own necessities, but of their advantages.

Adam Smith, An Inquiry into the Wealth of Nations, vol. 1

The butcher, the brewer, and the baker see their self-interests realized in the property rights that they are given under society's property-tax bundle of rights. The state keeps the rest. There was a time when this might have meant giving prime meat, mead, and meal to the King, and keeping the balance for one's own use and barter. Today for most adult Americans it means working, paying taxes, and saving what one can. Always and everywhere there is both a private and a public component to ownership. People work to get what the state allows them to own, in the manner that the state allows them to own it, and the state takes its share. This is the property-tax bundle of rights, the atomic unit of private market capitalism.

This section sets out the elements essential to any conception of a property-tax bundle: the rights of property; the term structure of ownership; the timing and rate structure of taxation; and the idea of property as command over fungible wealth or capital. Society can combine these elements in different forms to create different property-tax bundles.

\section{The Rights of Property}

We start with the rights in property's "bundle of rights" as learned in a typical law school curriculum. These rights exist as of any moment in time; they are what a property owner "has" or 
"holds" today. There are various descriptions of the bundle that legal scholars take to constitute "ownership" of property, all towards the same end. We shall use the six "incidents of ownership" as set forth by Roscoe Pound:

(1) the jus possidendi or right of possessing;

(2) the jus prohibendi or right of excluding others;

(3) the jus disponendi or right of disposition or alienation;

(4) the jus utendi or right of using;

(5) the jus fruendi or right of enjoying the fruits or profits; and

6) the jus abutendi, or right of destroying or injuring if one likes. ${ }^{20}$

As suggested by the Latin, these rights have been brought down from Roman law. ${ }^{21}$ Pound's formulation is a comprehensive list of a property owner's powers. We can divide the six rights into two sets. The first triad -- the rights to possess, exclude, and dispose or alienate property (jus possidendi, probibendi, and disponendi) -- constitute what we call "control rights." These rights allow the property owner to manage and conserve property, typically with a view of increasing its value -- by possessing it against strangers, excluding non-owning users, and transferring the property to others, on sale, death, or otherwise. The second triad -- the rights to use, enjoy the fruits of, and abuse the property (jus utendi, fruendi, and abutendi) constitute "use rights." These rights allow the property owner to consume her wealth and thereby to dissipate its value, all the way to the limiting case of

\footnotetext{
${ }^{20}$ Roscoe Pound, “The Law of Property and Recent Juristic Thought," 25 ABA Journal 993 1939) at 997. See also A. M. Honore, "Ownership" in A.G. Guest, ed., Oxford Essays in Jurisprudence (1961); J. E. Penner, "The 'Bundle of Rights' Picture of Property," supra. We discuss Honore's conception and suggest how it converges with Pound's infra Section 4.

${ }^{21}$ See generally BARRY NICHOLAS, AN INTRODUCTION TO ROMAN LAW, (1962).
} 
using it all up (the jus abutendi).

The use rights are central to the change from an absolute to a fiduciary conception of the property-tax bundle. The usufruct is the central legal element of the fiduciary bundle, returning to certain moral intuition set forth by Locke and contemporaries. ${ }^{22}$ A usufruct literally consists of the jus utendi and fruendi without the jus abutendi; it takes the right to waste out of the bundle of a present owner's rights, leaving an owner with five of Pound's six incidents of ownership. It was an attractive idea for Jefferson vis a vis the physical resources of the Earth. It is an attractive idea for a reasonable democratic society today vis a vis all wealth.

\section{The Term Structure of Property}

There is no property without time. The rights of property just canvassed mean little if they do not endure through time: the child clutching a toy while crying out "mine" is right, up to a point. Much of the first year curriculum, as it is now and has been taught since Christopher Columbus Langdell initiated the modern American law school in the late nineteenth century, ${ }^{23}$ concerns the temporal estates, present and future interests and so forth. The question is, for how long does one hold the static rights of property.

The fee simple absolute is the default answer in America today and under the absolute conception. This term stands as the star in a centuries-long movement up from feudalism, with its limited temporal terms. Largely for reasons of economic efficiency, the British land law long aimed

22 See generally Jeffrey Paul and Ellen Frankel Paul, Locke's Usufructuary Theory of Self-Ownership, 61 PPQ 384 (1980). For connections between Locke and other early British political theorists such as Filmer and utilitarianism, see A.P. Brogan, John Locke and Utilitarianism, 69 Ethics 79 (1959). For a philosophical discussion of the usufruct and deontological moral theory, see; Kenneth R. Westphal, Do Kant's Principles Justify Property or Usufruct? 5 Ann, Rev. of Law and Ethics 141 (1997).

${ }^{23}$ See Peter L. Strauss, Christopher Columbus Langdell and the Public Law Curriculum, 66 J. Legal Educ. 157 (2016). 
toward a form of infinite ownership with free powers of tetstation. The law had largely reached this milestone by Blacktone's time, notwithstanding lingering traces of primogeniture. ${ }^{24}$ The fee simple absolute became the default term under nascent American law; America was born into absolute ownership.

Under a fee simple absolute, the owner owns her property for all time. There are no separate temporal terms: no discrete present or future interests, no reversions or remainders. There is only the single fee or unit of ownership, spanning all of time. To have a graphic image in mind, if we think of time as a ray starting in the present and stretching out into an unending future, the fee simple absolute includes it all:

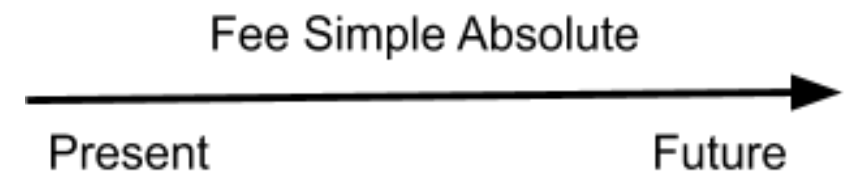

Figure 1: The Fee Simple Absolute

The fee simple absolute has become such a part of the American consciousness that it can be hard for ordinary moral intuitions to countenance any other form of ownership. Yet on a moment's reflection, the fee simple absolute is neither necessary nor intuitive. What can be intuitive about a finite mortal owning a thing for an infinite length of time?

A historically and even logically prior term of ownership is the life estate, where the owner owns her property for as long as she lives. A life estate, because it contains the present but does not extend into infinite time, generates the need for some future interest, such as a reversion to the state

\footnotetext{
${ }^{24}$ See generally C. Ray Keim, Primogeniture and Entail in Colonial Virginia, 25 William and Mary Q. 545 (Oct., 1968); Richard B. Morris Primogeniture and Entailed Estates in America, 27 Colum. Law Rev. 24 (1927).
} 
under the feudal form, or a remainder over to a named third party, who becomes a co-owner through time. After the expiration of the prior, life estate term, the reversionary or remainder holder steps into ownership, typically for a fee simple absolute (the default). In graphic terms:

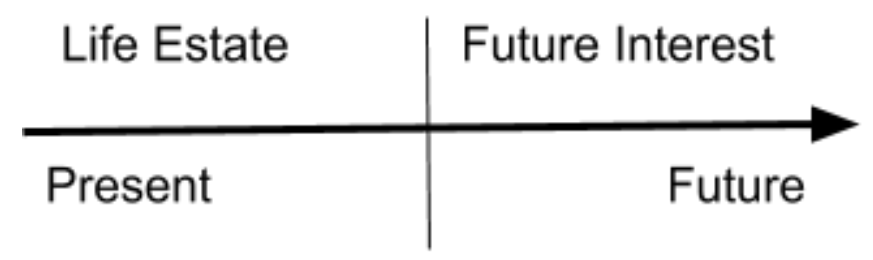

Figure 2: A Life Estate with Future Interest

The life estate term becomes central to the fiduciary conception of the property-tax bundle. The wealthy are made to act with solicitude for the future by not having the jus abutendi; they must leave capital for others.

\section{Two Components of Tax}

Tax affects property rights. This is the central reality of the property-tax bundle. The complexity of tax can obscure an understanding of the connections. Fortunately, we do not need much of the many possible details of tax to understand the two conceptions of the property-tax bundle under consideration. Basics are basic. We are concerned with broad analytic structures: with how a tax system affects property rights as a matter of law. Complexities can wait. Thus we add just two components of tax: one, the timing of its imposition and, two, its rate structure. For both components, we consider two cases: prepaid and postpaid for timing, flat and progressive for the rate structure. 


\section{The Timing of Tax}

Thinkers going back at least as far as Thomas Hobbes have considered questions about the timing of the imposition of tax in the context of broader questions of distributive and social justice. ${ }^{25}$ There are two primary times to tax: as wealth comes into and as it goes out of private households. Economists refer to a household "flow of funds," which in stylized terms looks like: Labor + Capital $=$ Income $=$ Consumption + Savings. Wealth comes into a household from payments for work (Labor) or from the return to savings and investment (Capital); wealth goes out of the household in the form of spending (Consumption) or non-spending (Savings).

One time to tax is when resources come into a household, on the returns to labor or capital or both combined. We call any such levy a "prepaid" tax. An income tax is a source-based or prepaid tax; the XVIth Amendment to the U.S. Constitution allows the Congress to tax "all incomes, from whatever source derived." ${ }^{26}$ Capital and labor are the two great factors of production and hence the two sources of income, both of which the U.S. income tax is supposed to tax. The Supreme Court, in the century-old case of Eisner v Macomber, defined "income" as the "gain derived from labor or from capital or from both combined."27 For reasons we discuss in the notes and explain further below, the absolute conception features no effective tax on capital. The tax of the absolute property-tax bundle is a prepaid wage tax. ${ }^{28}$

${ }^{25}$ HOBBES, LEVIATHAN, supra note - at 226 ("For what reason is there, that he which laboureth much, and sparing the fruits of his labour, consumeth little, should be more charged, then he that living idly, getteth little, and spendeth all he gets; seeing the one has no more protection from the commonwealth, than the other?).

${ }^{26}$ U.S. CONST. amend. XVI.

${ }^{27}$ Eisner v. Macomber, 252 U.S. 189, 207 (1920).

${ }^{28}$ This Article sets aside any direct tax on the yield to savings. This means that we are only considering taxing wages in the prepaid model, and only taxing consumption or personal spending in the postpaid model. In the tax policy literature, these are the two canonical forms of a "consumption" 
A second time to tax is on uses. This is the right-hand side of the flow of funds equation, what tax students can recognize as the Haig-Simons definition of Income: Income $=$ Consumption + Savings. ${ }^{29}$ This means simply that sources equal uses; all inputs become outputs. A postpaid tax comes due when resources are used in personal consumption or saved. Because we will once again ignore any direct tax on savings, we call this second model a spending tax. The focus on uses is important because it allows for property-tax bundles that constrain the use-rights of property, as the fiduciary conception does, not simply share in the source, as the absolute conception does.

\section{The Rate Structure of Tax}

The second dimension of tax is its rate structure -- with how the tax burden is shared across the range of the tax's base (wages or spending). Once again, we consider just two variants.

tax, and they are equivalent under certain basic assumptions, as we shall see below. There are several reasons to ignore any direct tax on the yield to capital. These do not involve the argument from most economists and a good many theorists that a consumption tax (which ignores the yield to savings as a matter of principle) is normatively preferable to an income tax. Indeed, the fiduciary property-tax conception does not feature a true consumption tax because of its progressive rates, which mean that the yield to capital will sometimes bear a positive tax burden. See Edward J. McCaffery, A New Understanding of Tax, 103 MICH. L. REV. 807 (2005) One, the actual tax system largely already ignores the yield to capital, and proposals keep emerging to make this treatment even more systematic. McCaffery, Death of the Income Tax, supra note -. Two, the federal "income" tax as we know it -- as it exists, in the statute, today -- has pure and simple models for both the prepaid and the postpaid, wage and spending, taxes. These come from the individual retirement account (IRA) provisions we consider momentarily as examples. Three, and most decisively, the central aim of this Article is to present the general concept of a property-tax bundle, and then to articulate two particular conceptions of it. We are presenting analytic possibilities, not pressing normative arguments.

29 "Personal income may be defined as the algebraic sum of (1) the market value of rights exercised in consumption and (2) the change in the value of the store of property rights between the beginning and end of the period in question." H. SIMONS, PERSONAL INCOME TAXATION at 50 (1938). See EDWARD J. MCCAFFERY, OXFORD INTRODUCTIONS TO U.S. LAW: INCOME TAX LAW 6-8 (2012) (discusing Haig-Simons definition).. 
One is a flat or flattened rate structure, where each taxpayer pays the same (or similar) rate, as a percent. The payroll tax has a flattened rate structure, and the contemporary U.S. income tax is surprisingly close to one. ${ }^{30}$

Two is a progressive rate structure, such as the income tax nominally has. Under a system of progressive marginal rates, each taxpayer goes through ranges of paying increasingly higher rates, with the brackets looking like rungs on a ladder. One might pay nothing, a $0 \%$ rate, on her first $\$ 10,000$ of wages or spending (the tax's “zero bracket"), and then a $10 \%$ rate on the next $\$ 20,000$ of wages or spending (without losing the advantage of the lower rate on the first dollars), and so forth. The top marginal rate under the income tax has exceeded $90 \%$ at times in American history, although this rate only applied to a handful, at best, of multi-million dollar earners. ${ }^{31}$ Under the cuts made under President Trump's Tax Cut and Jobs Act of 2017 (TCJA), the highest marginal rate bracket is $37 \%$ as we write. ${ }^{32}$ The fiduciary conception returns to the progressive rates of America's near past.

\section{Two Forms of Savings Accounts}

We can see precise models of the two property-tax bundles as two common forms of tax-favored savings accounts under the Internal Revenue Code ("IRC"). One is the "traditional" model of I.R.C. Sections $401(\mathrm{k})$ or 408. This allows for a deduction for savings upfront. The tax

\footnotetext{
${ }^{30}$ McCaffery, The Death of the Income Tax, supra note --. .

${ }^{31}$ For the history of the highest marginal income tax rate in America, see Historical Highest Marginal Income Tax Rates, TAX POLICY CTR. (Feb. 4, 2020), https://www.taxpolicycenter.org/statistics/historical-highest-marginal-income-tax-rates [https://perma.cc/3W8M-DCCT]. For a fascinating account of how these high tax rates were largely symbolic, see Carolyn C. Jones, Class Tax to Mass Tax: The Role of Propaganda in the Expansion of the Income Tax During World War II, 37 BUFF. L. REV. 685, 686 (1988)..

32 See Tax Cuts and Jobs Act of 2017 (TCJA), Pub. L. No. 115-97, \11021(a), 131 Stat. 2054, 2072-73 (codified as amended at I.R.C. $\$ 1$ (2018)).
} 
comes due not when money is first earned, as from wages, but later when it is withdrawn for consumption: this is a spending tax. Recall the Haig-Simons definition of Income, Income $=$ Consumption + Savings. If we subtract Savings from both sides of the equation we arrive at: Income - Savings $=$ Consumption. An "income" tax with an unlimited deduction for savings is a spending tax.

Two is the "Roth" model of I.R.C. Section 408A, named after William Roth, a Republican Senator from Delaware. ${ }^{33}$ Roth IRAs generate no tax deduction upfront but are never responsible for taxation again. With all savings taking place in unlimited Roth accounts, we eliminate capital as a taxable input in the flow of funds. Since we are not taxing capital as an input we have a wage tax. This is how the social security or payroll tax system works. One pays tax on her wages and never again. There is no need for a taxpayer even to keep track of her savings. An "income" tax with Roth IRA treatment is a wage tax. ${ }^{34}$

\section{Two Conditions of Equivalence}

Within the silos of tax theory, a standard teaching is that traditional and Roth savings account models, prepaid and postpaid taxes, are equivalent under two analytic conditions regarding the two components of tax we are considering, timing and the rate structure. The idea is simple to see.

${ }^{33}$ Bill Bischoff, How the New Tax Law Created a 'Perfect Storm' for Roth IRA Conversions in 2019, MARKETWATCH (Feb. 24, 2019), https://www.marketwatch.com /story/how-the-new-tax-law-creates-a-perfect-storm-for-roth-ira-conversions-2018-03-26

[https://perma.cc/4XRW-PX2A]; Amir El-Sibaie, What Rothification Means for Tax Reform, TAX FOUND. (Sept. 12, 2017), https://taxfoundation.org/what-rothification-means-for-taxreform/[https://perma.cc/9KAS-JRCG].

${ }^{34} \mathrm{McC}$ affery, Death of the Income Tax, supra. 
Consider Ant, an iconic figure of thrift. (Ant's friend Grasshopper, who consumes all that he can as soon as he can, has no Savings, and thus his Income is his Consumption, under the Haig-Simons definition of income. Grasshopper pays the same tax under the prepaid or postpaid, wage or spending, models). Ant makes $\$ 1000$ in wages which, independent of taxes, she saves. Over a certain period of time, the value doubles, to $\$ 2000$. There is a flat $40 \%$ tax rate. Under the wage tax model, Ant must pay $\$ 400$ in taxes on her initial $\$ 1000$ wages, but never need pay tax again. The $\$ 600$ she saves, after taxes, doubles. She is left with $\$ 1200$ to spend. Under the spending tax model, Ant need not pay any taxes upfront. She saves her full $\$ 1000$ of earnings. This doubles, to $\$ 2000$, at which time Ant moves to pull the money out of her account to consume. Ant then faces her $40 \%$ postpaid spending tax, which takes $\$ 800$, leaving her with $\$ 1200$ to spend. There is no difference with the prepaid model.

There are two conditions necessary for the equivalence to hold.

One, the tax rate must be the same at the pre- and postpaid times. In our example, it was a $40 \%$ flat rate. If the postpaid tax rate had been $50 \%$ while the wage tax stayed at $40 \%$, then Ant could only spend $\$ 1000$ under the spending tax model, less than the $\$ 1200$ she would have under the wage tax model. The two taxes would not be equivalent.

Two, the rate of return, or the growth in the savings, must be constant to the private individual across the two models. This second condition means that there must not be any "windfalls" for the equivalence of prepaid and postpaid taxes to hold. ${ }^{35}$ Suppose that, inside her tax-favored savings account, some modest investment Ant makes, even just buying a $\$ 1$ lottery ticket, returns her $\$ 10,000$. Under the wage tax model, Ant need never pay any tax on this windfall.

35 See Edward J. McCaffery, Tax Policy Under a Hybrid Income-Consumption Tax, 70 TEXAS L. REV. 1145 (1992). 
(Again, this is what happens as a matter of course with the payroll tax system.) Under the spending tax model, Ant will have to pay tax on her good fortune. Ant's tax-favored has not yet been taxed but will be one day. The government stands ready to share in the "private" gains when Ant moves to spend them.

\section{The Project of a Property-Tax Bundle}

Within the silos of tax, the analytics just discussed have morphed into an argument for flat taxes of all kinds, wage or sales-based, such as value-added taxes (VATs). ${ }^{36}$ The mental frame of tax has been to see the questions of timing and rate structure in the light of technical issues about the taxation of the yield to capital. Much tax policy literature has taken the above analysis as an argument that wage and spending taxes must have flat rates, to preserve the equivalence of the two models and to never place an affirmative tax burden on capital. The theory has helped to inform a politically-powerful flat-tax movement and the factual trend towards flattened wage taxation that we discuss below. Other scholars have debated for centuries, in both a utilitarian economic and a deontologic philosophical tradition, "ex ante" versus "ex post" approaches to questions of distributive justice. ${ }^{37}$

\footnotetext{
${ }^{36}$ See, e.g., ROBERT E. HALL \& ALVIN RABUSHKA, THE FLAT TAX (2d ed. 2007); Lawrence Zelenak, The Selling of the Flat Tax: The Dubious Link Between Rate and Base, 2CHAP. L. REV. 197 (1999); Steve Forbes, The Tax Code: Make It Flat, FORBES (Mar. 7, 2014), https://www.forbes.com/sites/steveforbes/2014/03/07/the-tax-code-make-it-flat/\#31880e2a7

e0e [https://perma.cc/HYG8-9QNE]; Daniel Mitchell \& William Beach, How the Armey-Shelby Flat Tax Would Affect the Middle Class, HERITAGE FOUND. (Mar. 12, 1996), https://www.heritage.org/taxes/report/how-the-armey-shelby-flat-tax-would-affect-the-middle-class[https:/ /perma.cc/W36R-TSCH].

${ }^{37}$ See generally Barbara H. Fried, Ex Ante/Ex Post 13 J. Contemp. Legal Issues 123 (2003-2004), and sources cited therein.
} 
Other than noting some of the analytic, factual predicates for one position or another, this Article sets such normative debates aside. Our primary task is analytic. We are concerned with property rights, with what one can do with her wealth as a matter of law under the differing conceptions of the property-tax bundle. We leave the choice of conception up to the reasonable society. We want to expand the range of imaginative possibilities for what "property" means.

The property-tax bundle is what the state offers its citizens: the terms of the deal, so to speak. A reasonable society designs a property-tax bundle to generate the normatively appropriate (that is, reasonably chosen) incentives to motivate its butchers, brewers, and bakers to produce its desired end state. In choosing a tax system, society necessarily chooses a property-tax system because tax affects property rights. And the two most important variables are the timing and rate structure of tax. Looking at the matter in terms of how it affects property rights, "never taxing capital" or "preserving the equivalence of prepaid and postpaid tax systems" are not compelling normative constraints that a reasonable society must adopt. The analytic fact of the equivalence of flat prepaid and postpaid taxes is not a reason to preclude analytic consideration of a progressive postpaid tax.

As we shall also discuss below, the timing and rate structure components are not in fact politically, practically or psychologically independent. There are different effects, real and conceptual, between predicating progressivity on sources versus uses. ${ }^{38}$ The absolute property-tax bundle has a flat wage tax. There are sound reasons in economics and moral theory why a wage tax ought to have a flattened rate structure. ${ }^{39}$ We do, in fact, to first approximation, largely have a

\footnotetext{
${ }^{38}$ See McCaffery, A New Understanding of Tax, uspra note -. .

${ }^{39}$ See J. A. Mirrlees, An Exploration in the Theory of Optimum Income Taxation, 38 REV. ECON. STUD. 175 (1971).
} 
flattened wage tax, in part because our absolute conception of property has led to the evisceration of all meaningful "second" taxes on wealth. The fiduciary property-tax bundle has a progressive spending tax. This tax works together with a limited conception of private property rights to constrain how owners can use "their" capital. The particular fiduciary conception we discuss below actually works like a flat wage for the vast majority of Anericans, the $99 \%$ at the bottom of the wealth and income scales. But the top $1 \%$ are made to become fiduciaires over their capital, managing it for the ultimate benefit of others; they will hold their wealth in usufruct.

These are different property-tax systems, differing in both their property and tax dimensions. This Article is not rehashing the income-versus-consumption debate familiar to tax policy scholars, nor is it pressing an economic argument over the nontaxation of the yield to capital. A reasonable society might well want a spending tax in part because it gets at capital windfalls, and may choose to have a progressive spending tax in part because it wants the pattern of incentives and disincentives that such a property-tax bundle generates for its butchers, brewers, and bakers. We are not solving a mathematical equivalence. We are designing a property-tax system, and deciding who gets to do what with our nation's wealth, all to shape the kind of people we are and can reasonably hope to become. $^{40}$

\section{Money as Property}

The influential contemporary property scholars Thomas Merrill and Henry Smith have lamented the general lack of property theory development, and have specifically called for more

\footnotetext{
${ }^{40}$ See JOHN RAWLS, POLITICAL LIBERALISM (1993).
} 
attention to the "in rem" view of property, Latin for "about a thing." 41 While this Article agrees with the lament over the lack of critical attention to our theories of property, our immediate project is orthogonal to an in rem perspective. The property-tax bundle looks to what private individuals can do with their capital, or fungible wealth. We look to money as property.

It turns out that money has slipped through the cracks between the silos of our thoughts. In the utilitarian tradition of Western liberal property thought, we give people absolute private property rights in specific things because this is the best way we know, from Locke, David Hume, Blackstone, Smith, Coase, Demsetz and centuries of experience, to maximize the wealth of our nation. The control rights given to private individuals ensure that all specific assets flow to their highest and best use and users. The self interest, not the benevolence, of butchers, brewers, and bakers constrains the use-rights and mitigates abuse. This is the genius of the common-law absolute conception: there is an alignment of private and public interest, a natural harmony, in the use of every asset. Where there is not, we tweak the law of things here and there, as by imposing shorter term limits on intellectual property or environmental restrictions on land use. ${ }^{42}$ An unthinking acceptance of this happy convergence is what troubles Merrill and Smith and others.

Traditional property theory stops there, not developing any specific rules about the use of money, fungible wealth. But money comes from things. The absolute owner of things has absolute access to the wealth of her things in money or money's worth. Modern financial economies have made it easy for the wealthy to monetize their assets, that is, to extract the general value from their

\footnotetext{
${ }^{41}$ Thomas W. Merrill and Henry E. Smith, What Happened to Property in Law and Economics? 111 Yale L.J. 357 (2001. See also Thomas W. Merrill \& Henry E. Smith, Optimal Standardization in the Law of Property: The Numerus Clausus Principle, 110 Yale L. J. 1 (2000).

${ }^{42}$ For criticism and questioning of the efficiency of property doctrine, see Duncan Kennedy and Frank Michelman. Are Property and Contract Efficient?, 8 Hofstra Law Rev.:711 (1980); Carol Rose, Canons of Property Talk, or Blackstone's Anxiety, 108 Yale Law J. 601 (1998); Merrill and Smith, What Happened to Property in Law \& Economics?, supra.
} 
specific holdings. We monetize when we borrow, as against our home equity or, in the case of student loans, against our inchoate human capital. When we monetize we pull all of our personal capital -- the value of all of our things held through infinite time -- into our present pockets. The fully monetized individual can spend all of her capital and die broke, all while her specific assets or things continue to be managed efficiently. Borrowing against one's home equity or taking out a margin loan on a stock account generates this effect.

Under current American laws, spending it all and dying broke is in analytic fact an optimal hedonic path to pursue. ${ }^{43}$ It is a tax-free path. ${ }^{44}$ Modern tax laws fail to follow the money. The law generally fails to tax the yield to capital. It specifically fails to tax the monetization of things. Both property and tax theory fail to think through the relevance of widespread monetization to their core conceptions. The result is that there are no limits on an owner's use of money. And there is no reason -- other than individuals' benevolence -- to expect any alignment of private and public when it comes to the use of money.

In our property theories, the ownership of money has all of the rights of things attached to it without having the same reasons for having those rights. An owner can easily extract the monetary value from her specific assets. She can do whatever she wants with the resulting cash. She is not constrained by self-interest not to spend it in a way that harms society. She can waste it and harm us all. This is a potentially fatal flaw in the absolute conception, becoming ever more exposed in the twenty-first century, as more and more billionaires roam our social landscape.

\footnotetext{
${ }^{43}$ SEE STEPHEN M. POLLAN AND MARK LEVINE, DIE BROKE (1997).

${ }^{44}$ See Edward J. McCaffery, Taxing Wealth Seriously, 70 Tax L. Rev. 305 (2017).
} 


\section{Money in Locke}

Locke published his Second Treatise on Government in 1689, nearly a century before Blackstone's Commentaries gave full voice to the absolute conception. Locke's main object in his Treatises was to counter an argument for the divine right of kings, most powerfully made out by Sir Robert Filmer, ${ }^{45}$ by showing that private property precedes the state, which comes about by the tacit consent of its people. The Second Treatise features a naturalistic account of how property rights evolve in a state of unregulated nature. It turns out we start in usufruct.

Before arriving at the subject of property, Locke lays down the foundations of his theory, most importantly in Section 6 of the Second Treatise. "But though this be a State of Liberty, yet it is not a State of License," Locke begins, in language that has been forgotten by many of today's everyday libertarians. ${ }^{46}$ "The State of Nature has a Law of Nature to govern it," 47 and that law of nature is essentially to do no harm. Man in the state of nature "has not Liberty to destroy himself, or so much as any Creature in his possession, but where some nobler use, then its bare Preservation calls for it."48 God has given Nature to humans in usufruct. Rights are contingent on "nobler use." One cannot even "destroy" oneself; there is no jus abutendi over the self. ${ }^{49}$

When he comes around to the topic of personal property, Locke begins like a good first year law student today, considering things such as wild animals and pieces of fruit. In Section 37 of the

\footnotetext{
${ }^{45}$ Robert Filmer, Patriarcha (1680), The Necessity of the Absolute Power of All Kings (1648), available in Johann P. Sommerville, editor, Filmer: Patriarcha and Other Writing (1991).

${ }^{46}$ Locke, Second Treatise, Section 6 (emphasis in original).

${ }^{47} \mathrm{Id}$.

${ }^{48} \mathrm{Id}$.

${ }^{49}$ See Paul and Paul, Locke's Usufructuary Theory of Self Ownership, supra.
} 
Second Treatise, he gives one of several formulations of his celebrated labor or appropriation theory of property:

Before the appropriation of land, he who gathered as much of the wild fruit, killed, caught, or tamed, as many of the beasts, as he could; he that so imployed his pains about any of the spontaneous products of nature, as any way to alter them from the state which nature put them in, by placing any of his labour on them, did thereby acquire a propriety in them: but if they perished, in his possession, without their due use; if the fruits rotted, or the venison putrified, before he could spend it, he offended against the common law of nature, and was liable to be punished; he invaded his neighbour's share, for he had no right, farther than his use called for any of them, and they might serve to afford him conveniencies of life. ${ }^{50}$

One obtains "property" or "ownership" of things like animals and fruit by appropriating them from Nature via labor. But what follows is not the absolute conception of Blackstone. Locke does not assume an automatic harmony between the private and public interests. Ownership is contingent on social good deriving from private ownership. If the "fruits rotted" or the "venison putrefied," the owner-appropriator not only loses his property right; he is also "liable to be punished."

This idea of "punishing" an owner for "invad[ing] his neighbor's share" fits the analytic features of a usufruct, a term in vogue at the time of both Filmer and Locke, to which we shall return in Thomas Jefferson's famous invocation below. The Earth's or Nature's being held in usufruct means that living individuals can use but not destroy or waste Nature; allowing fruit to rot would be an exercise of the jus abutendi, which a usufructuary lacks. The fiduciary conception will generalize the point and predicate it of wealth. Private capital will be held in usufruct for the living.

${ }^{50}$ Locke, Second Treatise, Sec. 37. 
To Locke it is the productive use of specific things before they rot or waste that justifies private property. This is all very specific and physical: putrid meat and rotten fruit are not just metaphors, they are real examples of the misuse of an asset, Nature. In Section 38, Locke turns to land, another specific instantiation of property, a part of the Earth:

The same measures governed the Possession of Land too: whatsoever he tilled and reaped, laid up and made use of, before it spoiled, that was his peculiar Right; whatsoever he enclosed, and could feed, and make use of, the Cattle and Product was also his. But if either the Grass of his Inclosure rotted on the Ground, or the Fruit of his planting perished without gathering, and laying up, this part of the Earth, notwithstanding his Inclosure, was still to be looked on as Waste, and might be the Possession of any other. ${ }^{51}$

This is the familiar two parts of property rights. One obtains rights through labor but can lose them through waste or misuse. Ownership of land is conditional on the use one makes of the property; misuse or abuse puts that right in jeopardy or forfeits it altogether. This remains a usufruct.

Money has not yet entered the stage. Locke sees that there is little reason to waste without money:

What reason could any one have there to enlarge his Possessions beyond the use of his Family, and a plentiful supply to its Consumption, either in what their own Industry produced, or they could barter for like perishable, useful Commodities, with others?. . . For I ask, What would a Man value Ten Thousand, or an Hundred Thousand Acres of excellent Land, ready cultivated, and well stocked too with Cattle, in the middle of the in-land Parts of America, where he had no hopes of Commerce with other Parts of the World, to draw Money to him by the Sale of the Product? It would not be worth the inclosing, and we should see him give up again to the wild Common of Nature, whatever was more than would supply the Conveniences of Life to be had there for him and his Family.

${ }^{51}$ Locke, Second Treatise, Sec. 38. 
Thus in the beginning all the World was America, and more so than it is now; for no such thing as Money was anywhere known. ${ }^{52}$

Without the ability "to draw Money to him by the Sale of the Product," no individual has any obvious reason to try and take more property than he needs. It is unlikely that any forfeiture will obtain by waste. There is "as much and as good" property available for others, as Locke had put it in Section 33's famous "provisio," 53 such that all is fair as well as productive. There is harmony between private and public interests.

But, finally, money changes things:

But since Gold and Silver, being little useful to the Life of Man in proportion to Food, Rayment, and Carriage, has its value only from the consent of Men, whereof Labour yet makes, in great part, the measure, it is plain, that Men have agreed to disproportionate and unequal Possession of the Earth, they having by a tacit and voluntary consent found out a way, how a man may fairly possess more land than he himself can use the product of, by receiving in exchange for the overplus, Gold and Silver, which may be hoarded up without injury to any one, these metals not spoleing or decaying in the hands of the possessor. This partage of things, in an inequality of private possessions, men have made practicable out of the bounds of Societie, and without compact, only by putting a value on gold and silver and tacitly agreeing in the use of Money. (emphasis supplied) $^{54}$

${ }^{52}$ Locke, Second Treatise, Sections 48-49.

${ }^{53}$ Nor was this appropriation of any parcel of land, by improving it, any prejudice to any other man, since there was still enough and as good left, and more than the yet unprovided could use. So that, in effect, there was never the less left for others because of his enclosure for himself. For he that leaves as much as another can make use of, does as good as take nothing at all. Nobody could think himself injured by the drinking of another man, though he took a good draught, who had a whole river of the same water left him to quench his thirst. And the case of land and water, where there is enough of both, is perfectly the same.

Locke, Second Treatise, Section 33. Robert Nozick coined the phrase "Lockean proviso" to describe this passage. ROBERT NOZICK, ANARCHY, STATE AND UTOPIA (1974).

${ }^{54}$ Locke, Second Treatise, Sec. 50. 
The introduction of money into the story of property has two effects, one positive from the social point of view, one negative. Locke sees the upside. The ability to freely sell things -- the jus disponendi as to the whole of any specific asset -- eliminates an incentive to mismanage the asset in order to extract more value in the present, given robust private markets and easy monetization.

Consider an aging Ant who owns a farm worth $\$ 10$ million that she no longer has any personal interest in managing. She also lacks any intergenerational benevolence; her children have been well provided for. Optimal efficient management of the farm suggests some near-term restraint in its use; letting a portion of the field lie fallow, rotating and tilling soil for dynamic maximization, and so on. Ant's short personal time frame suggests the opposite: plucking the fruit now and using up every last unit of soil while she is alive. Under the absolute conception, the aging Ant still has every reason to show restraint and maximize the value of the farm, as by hiring professional farmers, as long as she can sell or borrow against the farm's equity. The specific asset, the farm, will be managed in alignment with the wealth of the nation even as its value can be used however Ant sees fit, social benefit or not. The ability to borrow against one's home makes one more, not less, concerned with its value.

Locke sees this upside but does not see the second effect. Monetization ensures that an unregulated private market of finite individuals will manage assets to produce the greatest wealth of the nation through infinite time. But monetization also creates an asset, the money being exchanged for or lent against the specific assets. A theory that is concerned about the use of assets should be concerned with the use of this asset, money. Things can be removed from usufructure, because Nature and self interest provide a constraint against the waste of things. But that is not true for money. Absolute power over money gives private citizens ample opportunities to harm others or 
the collective. The cardinal rule of Locke's State of Nature, to do no harm, lacks an enforcement mechanism against the power of money.

\section{Missing a Point}

Locke misses the potential social downside from misuse of money in large part because he also sees money as a thing: gold or silver coin. Unlike fruit, animal carcasses, or land, money "may be hoarded up without injury to anyone" because "these metals [do] not spoil or decay in the hands of the possessor." No one can waste money, and the condition on one's continued ownership of an asset -- avoid letting it rot or spoil -- never fails.

Metaphysics and monetarism aside, what is relevant to the project of the property-tax bundle are the property rights that individuals hold over their assets. What is most particularly relevant are the use-rights, and what is most problematic is the jus abutendi. Under Locke's text, one has a usufruct in the state of nature because one lacks the jus abutendi; letting property rot or waste sacrifices one's right and may even open one up to liability. We arrive at the absolute conception of property by Blackstone's time not because society decided in the interim that allowing fruit to rot or carcasses to putrefy was now to be encouraged. In a monetary economy, there should rationally be no waste of specific property. People can be expected to use assets such as land reasonably, exercising the jus utendi et fruendi, but not unreasonably, exercising the jus abutendi. Self-interest prevents waste.

Ironically, then, the earth is held in usufruct under the absolute conception because the self interest of the present checks the right to waste. This was true in Locke's State of Nature (where all the world was America) and it continues to be true in a monetized economy with the full private jus disponendi. A naive or simplistic acceptance of this thesis furthers Merrill and Smith's lament: Coasean 
theory assumes that no more particular theory of property is needed, because absolute property rights plus self interest, alone, lead to optimality. ${ }^{55}$ Absolute ownership without the right to waste is a usufruct. A fully monetized economy keeps things in usufruct by fact, not law.

The advent of money into the economy, however, only transfers the problem of potential waste or divergence from things to money. The efficiency of the absolute conception, as confirmed by Coase, only works for the specific assets that can be monetized. Locke does not ask the next question, about the use of money, because he sees money as a thing that cannot rot or spoil. And to be fair and charitable to Locke and his times, the modern extent of both wealth and monetization was surely unimaginable until quite recently.

Still, Locke makes a logical mistake. It is not the thing, but the use-rights over the thing, that a property-tax bundle sets. The reasonable society gives its private citizens all three use rights over property, because this is the best way to prevent the wasteful use of any specific asset. The nature of the asset does not prevent its waste; self interest in its use does. Fruit does not not rot because of the nature of fruit; fruit does not rot because we have given property rights to individuals to encourage them to use, not misuse, the fruit (and the tree and the land). Gold and silver coins do not rot, but the private uses of great wealth can be publicly noxious. .

Here then is the paradox. A reasonable society does not want to waste property. Waste harms the society at least in an opportunity cost sense, as the state is the co-owner of wealth under the property-tax bundle; any failure to maximize the wealth of the nation costs the state material resources. The reasonable society gives all of the use rights in things to a single owner in order to

\footnotetext{
${ }_{55}$ Merrill and Smith, What Happened to Property in Law \& Economics?, supra note -..For an interesting perspective also calling for more exploration of property law in the context of distributive justice, see David Blankfein-Tabachnick \& Kevin A. Kordana, Kaplow and Shavell and the Priority of Income Taxation and Transfer, 69 Hastings L.J. 1 (2017).
} 
prevent the exercise of a use right, the jus abutendi. People do waste assets they hold in usufruct or life estate, but not one they hold absolutely. If the state were to assign a specific asset randomly, it would end up being put to its highest and best use as long as its owner has absolute property rights: this is the Coase theorem. Monetization allows the process to proceed apace, across all of time, such that things can be set free. But monetization also creates a discrete asset, the money representing the capital value of the specific assets. And self interest does not constrain an owner from exercising her jus abutendi over money in a way that is wasteful vis a vis the wider society. Indeed, self interest encourages waste in just this sense.

Gold does not spoil. But allowing people to "consume, waste, or destroy" all of the gold that they can get their hands on at any moment in time can spoil reasonable democratic governance. Absolute use-rights can spoil absolutely. A fiduciary property-tax bundle of rights is a legal mechanism to prevent America's private capital from rotting or putrefying to the detriment of the wider society. It puts money itself (back) in usufruct. 


\section{The Absolute Property-Tax Bundle}

There is nothing which so generally strikes the imagination, and engages the affections of mankind, as the right of property; or that sole and despotic dominion which one man claims and exercises over the external things of the world, in total exclusion of the right of any other individual in the universe.

William Blackstone, Commentaries on the Laws of England, Book II, chapter $1^{56}$

\section{Property Concepts}

Under the absolute conception, private property holders have unlimited powers over their things. In space, at least in the case of land, the owner's rights stretch from the center of the earth to the heavens: ab orco ad coelum, in Blackstone's simple Latin. ${ }^{57}$ At any point in time, the owner has all six of Pound's powers: she can both control and use her own property, free from government interference. The absolute owner can possess her property (jus possidendi); exclude others from it (jus probibendi); buy, sell, encumber or otherwise transfer it, on life or at death (jus disponendi); use it (jus utendi); enjoy its "fruits" or profits (jus fruendi); and altogether destroy it if she likes (jus abutendi). The absolute owner need not ask anyone's permission to do any of these things, and no non-owner has any general right to complain about her exercise of these rights.

An owner also owns her property through all of time, with no even possible contingent future interest to challenge her present powers. America was born to the fee simple absolute term structure, which the British land law had mainly reached, after a more-than-millenium long journey,

\footnotetext{
${ }^{56}$ BLACKSTONE, COMMENTARIES at Book II, Chapter 1, p.1.

${ }^{57}$ Id at Book II, Chapter 2, p. 18.
} 
by the time of Blackstone, Smith, and the American Revolution. ${ }^{58}$ The fee simple absolute or, more simply, the fee simple, stands at the core of the absolute conception of the property-tax bundle that first year law students learn An internet search reveals the sweep of the term:

The greatest possible estate in land, wherein the owner has the right to use it, exclusively possess it, commit waste upon it, dispose of it by deed or will, and take its fruits. A fee simple represents absolute ownership of land, and therefore the owner may do whatever he or she chooses with the land. If an owner of a fee simple dies intestate, the land will descend to the heirs; ${ }^{59}$ and

A "fee simple absolute" is what one typically thinks of when someone else "owns" something. Typically, this is an interest in property a person will receive when they either buy land or receive land as a gift. The interest is absolute because the interest will not end on the occurrence of an event or condition. ${ }^{60}$

The sense of ownership in these passages is simple, sweeping, absolute.

It is remarkable how much a matter of common sense the absolute conception has become to Americans. Relatively few non-lawyers likely know the phrase "fee simple absolute." Yet virtually all Americans understand the concept, the idea that ownership is forever with no specific future interest standing in the way, and that no one has any right to tell you what you can do with your own property. The fee simple absolute has attractive economic properties, including addressing the tragedy of the commons by internalizing to the owner the costs of dynamic, or future-oriented, mismanagement, an insight developed by the late Harold Demsetz. ${ }^{61}$

\footnotetext{
${ }^{58}$ See generally DONALD R. DENMAN, ORIGINS OF OWNERSHIP: A BRIEF HISTORY OF LAND OWNERSHIP AND TENURE IN ENGLAND FROM EARLIEST TIMES TO THE MODERN ERA, 2ND ED. (1958); JOHN HUDSON, LAND, LAW, AND LORDSHIP IN ANGLO-NORMAN ENGLAND (1994); JOHN J. LAWLER AND GAIL GATES LAWLER. A SHORT HISTORICAL INTRODUCTION TO THE LAW OF REAL PROPERTY. WASHINGTON, D.C.: BEARD BOOKS, 2000 (1940); A.W.B. SIMPSON, A HISTORY OF THE LAND LAW, 2ND EDITION.(1986).

${ }^{59} \mathrm{https}$ ://legal-dictionary.thefreedictionary.com/Fee+simple+absolute

60 https://www.legalmatch.com/law-library/article/fee-simple-and-fee-simple-absolute.html

${ }^{61}$ Demsetz, Towards a Theory of Property Rights, supra. See also Garrett Harden, The Tragedy of the Commons, 162 Science 1243 (1968).
} 
All of these absolute powers for all of time extend to the ownership of money, or fungible wealth. Indeed, there are some limits to what owners can do with some of their property, like those provided by environmental regulations and land-use controls. But such limits are imposed on specific instantiations of property., in rem. Owners have absolute and infinite powers over their fungible wealth or capital.

This is where traditional property concepts end, with individuals having absolute power over the money in their pockets. Property leaves money on the doorstep of Tax. It turns out that Tax does not open the door..

\section{Tax Concepts}

The absolute property-tax bundle has a flattened, prepaid wage tax. This essentially describes America's current tax system. ${ }^{62}$ A wage tax leaves an owner with absolute power over the money in her pocket. That is all we need for understanding the analytics of the absolute property-tax bundle. Both the payroll tax system in full and the Roth-style savings accounts under the income tax provide precise examples. Once one has paid tax on her wages, she need never pay payroll tax on those dollars and will escape all future income taxes by placing the dollars in a Roth account. She can pull the money out at any time and spend as she pleases, without being liable for any further tax.

Although this is all that is needed to understand the absolute property-tax bundle, it is helpful to look at the development of both our tax system and our ideas about tax over time, as we are doing with property. We see how our tax conceptions have evolved in the shadows of the

\footnotetext{
${ }^{62}$ See McCaffery, Death of the Income Tax, supra.
} 
preexisting property conceptions to merge into an absolute property-tax bundle in fact, leaving us with a flattened wage tax. We see how, operating in isolation of property law and theory, tax law and theory also fails to limit private power over wealth. Capital emerges as completely private, outside the reach of tax or social regulation. Indeed, private capital's march toward absolute power will not end until it has defeated all taxes levied against it and then slayed the veritable Rule against Perpetuities to boot.

We begin on this conceptual journey with a return to Locke and his labor appropriation theory of property. Centuries later we still feel that we have earned our wages. In "everyday libertarianism," as Murphy and Nagel see it, ideas about property, earnings, entitlement, and desert attach such a strong sense of absolute ownership to individual labor earnings that any subsequent state imposition of taxes seems suspect:

At the everyday level of what it feels like to live and work in a capitalist economy, the sense of entitlement to net income is firmer than that --- we are inclined to feel that what we have earned belongs to us without qualification, in the strong sense that what happens to that money is morally speaking entirely a matter of our say-so. Though everyone knows that even the right to spend the money in our pockets is circumscribed, for example, by the obligation to pay applicable sales taxes, the instinctive sense of unqualified ownership has remarkable tenacity (emphasis in original). ${ }^{63}$

This is the mental frame of the absolute conception, an "instinctive sense of unqualified ownership" in our "net income," the money we get to keep in our pockets after an initial payment of taxes. Ordinary Americans may know at some level that "even the right to spend money in our pockets is circumscribed, for example, by the obligation to pay applicable sales taxes." But under the absolute conception this is a modest aside, and in reality it is not even true: one can move to a jurisdiction

${ }^{63}$ MURPHY AND NAGEL, supra at 34-35 
without sales taxes, such as New Hampshire, Delaware, or Oregon. ${ }^{64}$ The idea that tax law can in fact deliberately circumscribe the right to spend money is a central insight of the fiduciary property-tax conception to be developed. Meanwhile, the absolute conception and its view of wealth, namely that an individual has an unqualified entitlement to do whatever she wants with the money in her pocket, has had a "remarkable tenacity" both in America's popular understanding and in the development of its positive law.

When we turn to tax, the story we observed with property, as the law moved from usufruct to absolute ownership, repeats: Capital works itself free. We pay tax as we have to out of our paychecks. But the money that we are left with -- our "net income," as Murphy and Nagel call it -- is ours. It is all ours, only ours, forever ours. This attitude, and the money that goes with it, will go on to kill everything that stands in its way.

\section{Money Escapes the Income Tax}

First on the agenda was to get out of paying additional income tax on the returns to capital. John Stuart Mill criticized an income tax as a double tax on savings in $1848 .{ }^{65}$ His point is easy to see. Recall that both Ant and Grasshopper had earned $\$ 1,000$, but the thrifty Ant had saved her money while the spendthrift Grasshopper had spent all of his. Why should Ant be punished for her good behavior, and get taxed again when her money yields dividends? This would be a second tax on the money in Ant's pocket.

\footnotetext{
${ }^{64}$ See Melissa Parietti, States without Sales Taxes, Investopedia (last updated Jan. 22, 2020), available at: https://www.investopedia.com/articles/personal-finance/112415/5-states-without-sales-tax.asp\#: :text=Mo st $\% 20$ states $\% 20$ have $\% 20$ sales $\% 20$ tax $\% 2 \mathrm{C} \% 20$ New $\% 20$ Hampshire $\% 2 \mathrm{C} \% 20$ and $\% 20$ Oregon. ${ }^{65}$ JOHN STUART MILL, PRINCIPLES OF POLITICAL ECONOMY (1848)
} 
Everyday libertarians do not like "double taxation." Whatever generations of tax-law students might think of And and Grasshopper comparisons, everyday libertarians have little problem siding with Ant. And everyday libertarians have friends in high places. The influential conservative activist and devotee of President Ronald Reagan, Grover Norquist, published a seminal editorial piece, Step-by-Step Tax Reform, in 2003. ${ }^{66}$ Norquist explicitly articulated a widely held conservative goal of obtaining a tax system with "a single-rate tax, which taxes income one time." Increasingly, since Norquist first set out the plan in simple written form, the "one time" that "income" gets taxed is as it is earned from labor, just like the payroll tax, using Roth style savings accounts. Political conservatives in America have been on a decades-long quest to obtain the flattened prepaid tax of the absolute property-tax bundle. They are succeeding.

\section{Rothification}

The simplest path towards making the income tax a wage tax is to add savings accounts along the Roth IRA model and to repeal all limits on them. A fully "Rothified" income tax is not an income tax. It is a wage tax. Both the payroll tax and the "income" tax with Roth accounts embody the absolute property-tax bundle of rights precisely. One pays tax on her wages and then becomes the absolute owner of the resulting "net income" -- the money -- for all time. Roth-style treatment now extends to health and education savings accounts under the Internal Revenue Code, ${ }^{67}$ and there have been Republican led legislative proposals to make Roth treatment universal and unlimited. ${ }^{68}$

\footnotetext{
${ }^{66}$ Grover Norquist, Step-by-Step Tax Reform, WASH. POST (June 9, 2003).

${ }^{67}$ See IRC \529 (educational savings accounts), \ 223 (health savings accounts).

${ }^{68}$ See Brandon Duke, "Universal Savings Account" Proposal in New Republican Tax Bill Is Ill-Conceived, Center on Budget and Policy Priorities, updated Sept. 19, 2018, available at: https:/ www.cbpp.org/research/federal-tax/universal-savings-account-proposal-in-new-republican-tax-bill-is -ill-conceived
} 
Roth accounts are paradigms for the treatment of wealth under the absolute conception. They have no limits on use-rights and are not subject to any further tax within the owner's lifetime. Ant can use and spend the money in her account however she wants, any time she wants, tax free. And Roth accounts can get very large. During the 2012 presidential campaign the press discovered that Mitt Romney had a Roth IRA then valued at over $\$ 100$ million. ${ }^{69}$ By the end of 2016 , there were $\$ 2.36$ trillion in IRA accounts in America, at least a quarter of which are Roth-style. ${ }^{70}$ As with all capital accounts, we can expect that these are growing at rates higher than the national growth rate, as Piketty has shown with his fundamental force for divergence, the idea that the rate of return on capital, r, exceeds the growth rate, g, leading to a situation in which the rich get richer while workers struggle to keep up. ${ }^{71}$

\section{The Monetization Moment of Tax}

As it happens, the wealthy have never needed Roth IRAs to escape Mill's second tax. The nontaxation of the yield to capital under the U.S. income tax is quite general. ${ }^{72}$ Wealthy people have perfectly legally avoided the income tax's taxes on capital for over a century. We need not repeat the history or doctrinal details of tax at length. One central aspect of the story, however, bears

\footnotetext{
${ }^{69}$ See William D. Cohan, What's Really Going on With Mitt Romney's \$102 Million IRA?, The Atlantic (Sept. 10, 2012).

70 CRAIG COPELAND, EMP. BENEFIT RESEARCH INST., NO. 456, EBRI IRA DATABASE: IRA BALANCES, CONTRIBUTIONS, ROLLOVERS, WITHDRAWS, AND ASSET ALLOCATION, 2016 UPDATE 1 (2018), https://www.ebri.org/docs/default-source/ebri-issue-brief/ebri ib 456 iras -13aug18.pdf?sfvrsn=6a58352f_2 [https://perma.cc/2WGL-NS8K]; Roth Assets in Individual Retirement Accounts in the United States from 2000 to 2013, STATISTA RESEARCH DEP'T (Dec. 31, 2014), https://www.statista.com/statistics/187954/total-assets-of-roth-iras-in-the-us-since-2000/[https://perma.cc /G86D-459Z].

71 THOMAS PIKETTY, CAPITAL IN THE TWENTY-FIRST CENTURY (2013). For a sympathetic discussion of Piketty's analytics, see EDWARD J. MCCAFFERY, THE MEANING OF CAPITAL IN THE 21ST CENTURY (2016).

${ }^{72}$ See McCaffery, Taxing Wealth Seriously, suora.
} 
emphasis: how the income tax in its intellectual silo, like Locke before it, let money off the social hook.

The breakout moment came in 1920. The U.S. Supreme Court opinion in Eisner v Macomber held that the "mere" rise in value of corporate stock -- or, by extension, any other thing -- would not be taxable "income" until and unless there was some realization event, some derivation of capital (such as money from a sale) from the specific asset. ${ }^{73}$ The late Professor William D. Andrews famously called Macomber's realization requirement the Achilles' Heel of the income tax, because it allows for a simple buy-and-hold strategy to avoid Mill's second tax. ${ }^{74}$ Wall Street was only too happy to oblige its wealthy clients by designing financial assets -- things -- such as growth stocks that simply pay few or no cash dividends that the IRS could tax. Achilles' Heels are, by definition, fatal.

It was however not Macomber in isolation that set money free from income taxation. Ironically, the Justices in Macomber were clearly considering cash as at least a paradigm of a realization event to tax. In the facts of the case, the IRS was attempting to tax a stock-on-stock dividend, a paper transaction with no literal cash with which Mrs. Macomber could have paid a tax. But even in looking at money, the Justices missed its true power. The critical problem with Macomber is that it arose in the context of an income tax. Under an income tax, borrowing is not income. ${ }^{75}$ When one borrows she has a precisely offsetting obligation to repay her loan—she is, financially, no better off. Thus the proceeds of debt are not income. This is true under the U.S. income tax even when one borrows against appreciated assets. ${ }^{76}$ The appreciating assets that are not currently taxed under

73252 U.S. 189 (1920).

${ }^{74}$ William D. Andrews, The Achilles' Heel of the Comprehensive Income Tax, in NEW DIRECTIONS IN FEDERAL TAX POLICY FOR THE 1980S, at 278, 280 (Charles E. Walker \& Mark A. Bloomfield eds., 1984).

${ }^{75}$ See McCaffery, INCOME TAX LAW at 58.

${ }^{76}$ See Woodsam Assocs., Inc. v. Comm’r, 198 F.2d 357, 359 (2d Cir. 1952). 
Macomber can be used as collateral for loans. ${ }^{77}$ Borrowing thus allows the wealthy to monetize their unrealized appreciation without paying any tax.

This is not a minor academic matter. If Ant were to have bought a share of Berkshire Hathaway stock for $\$ 1000$ in 1965 , for example, the year Warren Buffet took over control of the company, that share would have grown to being worth more than $\$ 27,400,000$-- over twenty seven million dollars -- by the end of $2019 .{ }^{78}$ Only once in that time frame would any tax have been due, when Berkshire Hathaway (foolishly, in Buffet's telling), declared a ten cent per share dividend in 1967. ${ }^{79}$ In this simple example using public data, Ant would have the legal right to borrow and spend over twenty-seven million dollars, tax-free, however she pleases. This is what the absolute property-tax bundle of rights allows. President Donald J. Trump is aware of the strategy. The self-proclaimed "King of Debt" has, in publicly reported transactions, both personally borrowed hundreds of millions of dollars and paid no income tax for decades. ${ }^{80} \mathrm{He}$ is free to spend the money however he pleases.

\section{Money Escapes the Estate Tax}

Having effectively worked around any attempt to tax it again within an earner-owner's own generation, money next turned to eliminate any taxation on the intergenerational transmission of

\footnotetext{
77 See generally, MCCAFFERY, INCOME TAX LAW 12-15; see also Lawrence A. Zelenak, Debt-Financed Consumption and a Hybrid Income-Consumption Tax, 64 Tax Law Review 1-35 (2010).

78 John Maxfield, An Interesting Chart About Berkshire Hathaway, MOTLEY FOOL (July 23, 2017, 9:46 AM), https://www.fool.com/investing/2017/07/23/an-interesting-chart-aboutberkshire-hathaway.aspx [https://perma.cc/5TK8-U87E]. (last updated July 1, 2020)

79 Morgan Housel, Buffett: You Want a Dividend? Go Make Your Own, MOTLEY FOOL (Mar. 4, 2013),https://www.fool.com/investing/general/2013/03/04/buffett-you-want-a-dividend-go-make-your-ow n.aspx[https://perma.cc/8SWD-55AV].

${ }^{80}$ See Edward McCaffery, Trump is the King of Debt but Not of Taxes, CNN (Sept. 2, 2016, 8:11 PM), https://www.cnn.com/2016/09/02/opinions/trump-king-of-debt-but-not-taxes-opinion-mccaffery/index.ht $\mathrm{ml}$ [https://perma.cc/PD3S-93PW].
} 
wealth, so that Ant could give any excess wealth, beyond her own needs and reasonable wants, to her children, tax-free. This requires a brief consideration of the gift and estate, or wealth transfer tax system in the United States, popularly known as the "death tax." 1

Some version of this tax has been in place since 1916. Although the tax nominally falls on the transferor or donor -- her estate, in the case of a decedent -- the tax is effectively borne by the heirs because it reduces the capital they can inherit. We can understand the tax as an attempt to make sure that each generation pays at least an initial tax under the absolute conception; heirs who need not worry about wages should be taxed on their inheritance of capital as the initial source of their wealth.

Except that almost no estate pays an estate tax anymore. As with the income tax's non-taxation of capital, the estate tax's holes are transparent. There are generous exemptions from the tax explicit in the statute. After changes made under the TCJA, each person has an exemption level from the gift and estate tax of over $\$ 11$ million (the level is indexed for inflation, and so increases annually.) $)^{82}$ A married couple can transfer $\$ 22$ million to their children, in life or at death, completely tax-free. These large exemptions, among others, ${ }^{83}$ make the estate tax easy to avoid; $99.7 \%$ of decedent estates need not bother with it.

As with the case of the income tax and Roth accounts, it is not just the statute that makes the estate tax easily avoided. It has long been called a "voluntary tax." 84 President Trump's former

\footnotetext{
${ }^{81}$ See generally MICHAEL J. GRAETZ \& IAN SHAPIRO, DEATH BY A THOUSAND CUTS: THE FIGHT OVER TAXING INHERITED WEALTH (2005).

${ }^{82}$ See Julie Garber, Federal Estate Tax Exemptions 1997 Through 2019, THE BALANCE (Feb. 29, 2020), https://www.thebalance.com/exemption-from-federal-estate-taxes-3505630 https://perma.cc/WD6Y-T8R6].

${ }^{83}$ See generally GRAETZ AND SHAPIRO, supra; Edward J. McCaffery, Distracted from Distraction by Distraction: Reimagining Estate Tax Reform, 40 PEPP. L. REV. 1235 (2013).

84 See generally GEORGE COOPER, A VOLUNTARY TAX? NEW PERSPECTIVES ON SOPHISTICATED ESTATE TAX AVOIDANCE (1979); George Cooper, A Voluntary Tax? New
} 
chief economic advisor, Gary Cohen, helpfully explained that only "morons" pay it. ${ }^{85}$ The casino magnate Sheldon Adelson was able to get $\$ 8$ billion to his children, tax-free, as a matter of public record, at a time when the exemption level was $\$ 1$ million per person. ${ }^{86}$ And so on. As a practical matter, the estate tax does not stand in money's absolute way, should an owner want her money to stay in the family.

\section{Money Escapes the Generation-Skipping Tax (the Birth of Dynasty Trusts)}

In theory, the gift and estate tax aims to tax beneficent transmissions of wealth such that each generation must pay at least an initial tax on its sources of wealth. Then the absolute conception can take hold. The inheriting generation can live tax-free, using Roth accounts and other techniques as discussed above, until it dies. That generation then faces an estate tax on the way to the capital's passing to the next generation. Wealthy families, however, can afford to "skip" generations. Grandparents, in Generation 1, can pass wealth directly to grandchildren, in Generation 3, "skipping" the need to pay transfer taxes at Generation 2's death. Significantly, Generation 1 -- the present -- can also effect this same result using trusts, which now become a central part of the story, to prevent an infant in Generation 3 from obtaining absolute control.

Perspectives on Sophisticated Estate Tax Avoidance, 77 COLUM. L. REV. 161 (1977); Edward McCaffery, A Voluntary Tax? Revisited, 93 NAT’L TAX ASS'N PROC. 268 (2000).

${ }^{85}$ Robert Frank, 'Only Morons Pay the Estate Tax,' Says White House's Gary Cohn, CNBC (Aug. 29, 2017), https://www.cnbc.com/2017/08/29/only-morons-pay-the-estate-taxsays-white-houses-gary-cohn.html https://perma.cc/MVU3-CKEK]; see also Edward McCaffery, Tax Breaks for Multi-Millionaire Morons, HUFFINGTON POST (Nov. 2017), https://www.huffpost.com/entry/tax-breaks-for-multi-millionaire-morons b 59f9f06ae4b0b7f0915f6 35d [https://perma.cc/WKZ7-A4PG].

${ }^{86}$ Zachary R. Mider, Accidental Tax Break Saves Wealthiest American \$100 Billion, BLOOMBERG (Dec. 17, 2013), https://www.bloomberg.com/news/articles/2013-12-17/accidental-tax-break-saves-wealthiest-americans-100 -billion [https://perma.cc/KFU2-Y8LY]. 
A trust is a legal form, an entity created by contract, for the management and control of property. ${ }^{87}$ An initial owner, the Trustor, places specific assets in the Trust, to be managed by a designated Trustee for the ultimate use by named individuals, the Beneficiaries. The trust form allows the management and control of assets to be separated from the other incidents of ownership, namely the use-rights, and placed with a Trustee. ${ }^{88}$ It also allows absolute owners in Generation 1 to control the use -rights of their wealth from beyond the grave.

Under the transfer-tax laws, a Trustor in Generation 1 can set up a Trust for her heirs in Generation 2 and beyond but suitably limit the powers given to the Generation 2 members that the assets will not be subject to an estate tax on any Generation 2 person's death. These are now called Perpetual or Dynasty Trusts. ${ }^{89}$ Most significantly, a Beneficiary can have access even to the principal, or corpus, of the trust, as long as that access is limited by an "ascertainable standard," a term of art for estate planners meaning the beneficiary's reasonable needs for "health, education, support or maintenance," "HEMS" for short. ${ }^{90}$ With the trust mechanism, Generation 1 can now pass wealth directly to Generation 3, or can have a series of life estates starting at Generation 2, all skipping any tax at Generation 2. To shut the perceived generation-skipping loophole down, the Tax Reform Act of 1986 added a "generation-skipping tax," perfecting an earlier version of the law. ${ }^{91}$ Transfers from Generation 1 to Generation 3 or beyond now bear a double transfer tax.

\footnotetext{
${ }^{87}$ See John H. Langbein, The Secret Life of the Trust: The Trust as an Instrument of Commence, 107 Yale. L. J. 165 (1997).

${ }^{88}$ On the separation of ownership and control generally, see ADOLF AUGUSTUS BERLE AND GARDINER COIT MEANS. THE MODERN CORPORATION AND PRIVATE PROPERTY (1932).

${ }^{89}$ Jesse Dukiminier and James E. Krier., The Rise of the Perpetual Trust, 50 UCLA Law Review 1303 (2003); see also Steven J. Horowitz \& Robert H. Sitkoff, Unconstitutional Perpetual Trusts, 67 Vand. L. Rev. 1769 (2014); Eric Kades, Of Piketty and Perpetuities: Dynastic Wealth in the Twenty-First Century (and Beyond), 60 B.C. Law Rev. 165 (2019).

${ }^{90}$ See generally Christian S. Keslo, But What's an Ascertainable Standard: Clarifying HEMS Distribution Standards and Other Fiduciary Considerations for Trustees, 10 Est. Plan. \& Cmty. Prop. L.J. 1 (2017-2018).

${ }^{91}$ See Tax Reform Act of 1986, Pub. L. No. 99-514, 100 Stat. 2085 (1986).
} 
Only there is an exemption level for generation-skipping transfer taxes, too, initially set at $\$ 1$ million per transferor. This exemption provided a roadmap: a couple would place $\$ 2$ million or more (with "fractional share discounts" and other valuation techniques) into a generation-skipping tax-exempt trust that would never pay transfer tax. ${ }^{92}$ The exemption numbers have now increased, after the TCJA, to over $\$ 11$ million for an individual and $\$ 22$ million for a married couple. While as with the estate tax there are other means than the exemptions to avoid the generation-skipping tax -- Sheldon Adelson's $\$ 8$ billion wealth transfer was almost certainly generation-skipping -- these massive exemptions are enough to make the point that for at least large amounts of capital, all wealth transfer taxes are dead, forever. By 2003, with “just" the $\$ 1$ million per person exemption, one study put the amount of assets in domestic Dynasty or Perpetual Trusts at $\$ 100$ billion. ${ }^{93}$ That number has likely grown to over one trillion dollars $(\$ 1,000,000,000)$, more than the GDP of all but sixteen nations, with the passage of time and the radically higher exemption levels now available.

\section{Money Escapes the Rule Against Perpetuities}

Having created dynasty trusts free of wealth transfer taxation and bearing little or no income tax under basic tax planning techniques, the next question for our successful and intergenerationally minded butchers, brewers, and bakers is for how long could the trusts last. This is a matter of state property law. The dreaded Rule Against Perpetuities ("RAP”), a product of the Duke of Norfolk's Case from 1682, ${ }^{94}$ stood in the way of a present absolute owner having infinite control over her wealth. But not for long.

\footnotetext{
${ }^{92}$ See generally Edward J. McCaffery, Distracted from Distraction by Distraction: Reimagining Estate Tax Reform, 40 Pepp. L. Rev. 5 (2013)

${ }^{93}$ Robert H. Sitkoff \& Max M. Schanzenbach, Jurisdictional Competition for Trust Funds: An Empirical Analysis of Perpetuities and Taxes, 115 Yale L.J. (2005).

943 Ch Cas 1; 22 ER 931
} 
The rule states: "An interest must vest, if it is to vest, within a life in being plus twenty-one years," in John Chipman Grey's well known formulation. ${ }^{95}$ Property law students still slave over the hoary doctrine, because it is easy to test in a multiple choice format and hence a staple of multistate bar exams. Estate tax lawyers on the other hand plan for their actual living clients in a world without any RAP. For after the generation-skipping transfer tax exemptions spurred the creation of dynasty trusts, the RAP soon fell.

A typical dynasty trust works through a series of life estates. Each generation after the Trustor's has the right to income and some discretionary access to principal, limited by ascertainable standards. For transfer-tax purposes, this game can go on forever, because no generation after the Trustor's ever "owns" the capital for estate tax purposes. But at some point one runs out of "lives in being plus twenty-one years" or, more simply, ninety years in the uniform (USRAP) alternative. A moment in time comes when a state law RAP compels dissolution of a dynasty trust and distribution of all of its assets, in fee simple absolute, to the then beneficiaries.

No bother. The wealthy and their advisors launched a political campaign to repeal the RAP. ${ }^{96}$ At least seven states have now done so, importantly including Alaska and South Dakota, which have emerged as domestic trust havens in the United States. ${ }^{97}$ Because Trusts are a form of contract, wealthy Americans from California, New York, Massachusetts, Illinois, and other states can choose

${ }^{95}$ JOHN CHIPMAN GRAY, THE RULE AGAINST PERPETUITIES. 3RD ED. (1915).

${ }^{96}$ Robert H. Sitkoff, The Lurking Rule Against Accumulations of Income, 100 NW. U. L. REV. 501, 507-08 (2006) ("Since 1986, a host of states have abolished the Rule Against Perpetuities as applied to interests in rust. The driving force for this abrupt turn-about was not a careful consideration of the ancient policy against perpetuities, but rather a 1986 reform to the federal tax code. . . In a state that has abolished the Rule,successive generations can benefit from the trust fund, free from federal wealth transfer taxation, forever." (internal footnotes omitted)). Cades, supra note -.

${ }^{97}$ See Zachry Mider, South Dakota, Little Tax Haven on the Prairie, Bloomberg Businessweek (Jan. 9, 2014); Olivier Bullough, Great American Tax Haven: Why the Super-rich Love South Dakota, The Guardian (Nov. 14, 2019). 
to set up a South Dakota Trust, just as most major American corporations choose to reside in Delaware for legal purposes. The laws repealing RAP typically require that the assets be placed in a trust chosen to be governed by the state's law; that there be at least one state-resident Trustee; and that the Trustee have the power to sell or dispose of the individual assets (the jus disponendi). The last condition is the critical one. As long as today's Trustor provides that some Trustee will have the control powers over specific assets, the Trustor can dictate the terms of the use of her wealth forever. The Trustor has created a spendthrift trust, a usufruct over her own wealth. No one -- ever -- has the right to destroy her capital.

RIP, RAP. The absolute conception of the property-tax bundle reached its apotheosis in perpetual or dynasty trusts, in which hundreds of billions of dollars and growing now roam the American landscape, free of public tax or control, forever.

\section{What Butchers, Brewers, and Bakers Bequest}

As did Adam Smith, we can learn from butchers, brewers, and bakers. It is a fact that many of them have succeeded financially. Americans held nearly $\$ 100$ trillion of private wealth by 2018 , about $\$ 1.5$ million for every family of four. ${ }^{98}$ But most Americans do not have any significant wealth. The top one percent hold as much as $40 \%$ of the aggregate national net wealth, $\$ 40$ trillion of the social pie, more than the bottom $90 \%$ combined. ${ }^{99}$ This top 1 percent of households has an average net wealth over $\$ 10$ million; the top .01 percent exceed $\$ 100$ million. ${ }^{100}$ As of October, 2019 ,

\footnotetext{
${ }_{98}^{98}$ https://www.brookings.edu/blog/up-front/2019/06/25/six-facts-about-wealth-in-the-united-states/

99 https://www.washingtonpost.com/news/wonk/wp/2017/12/06/the-richest-1-percent-now-owns-more-of-t he-countrys-wealth-than-at-any-time-in-the-past-50-years/ 100 https://dqydj.com/net-worth-brackets-wealth-brackets-one-percent/
} 
there were 621 billionaires in America, and the wealthiest 400 Americans had a combined net worth of $\$ 2.9$ trillion. ${ }^{101}$

A reasonable society ought to be concerned over the use of money by this wealthiest group. This is rather by stipulation discretionary or excess private capital, well beyond ordinary needs and reasonable individual wants. Owners in this situation have demonstrated a temperament to save, to amass private capital. They have not, yet anyway, spent all of "their" wealth on themselves: This is part of the reason they are wealthy. Yet society faces a severe and growing moral hazard problem of private wealth. Rich owners can do anything they want with their money at any time under the absolute conception. What do the wealthy in fact do with their excess capital, and what can this tell us about designing a property-tax bundle for a reasonable democratic society that might appeal to even the most ambitious butchers, brewers, and bakers?

\section{Three Paths for Money, Two Types of Trusts}

People with more money than they personally need pursue three paths in some combination: the personal, the familial, and the philanthropic. We consider the personal path, spending beyond need within the owner's own generation, in the subsequent section. We now consider the familial and philanthropic paths. Today's owners can pursue either using trusts that are creatures of the absolute property-tax bundle.

The dynasty trust structure is how wealthy individuals direct the use of their wealth forever within their family. These trusts are beyond the reach of the RAP. They can last infinitely. Dynasty trusts typically give access to income but restrict access to principal for the current generation beneficiaries in a series of never-ending life estates; employ professional third-party trustees; and

${ }^{101}$ https://en.wikipedia.org/wiki/List of Americans by net worth 
have "spendthrift clauses" that prevent any current income beneficiary from alienating her entire interest. $^{102}$ This creates a usufruct over wealth: no individual, after the Trustor, has an unfettered right to the capital of the trust. Each beneficiary has the jus utendi and fruendi. None have the jus abutendi. Hundreds of billions of dollars at least are now in such form in America, ever growing.

Other butchers, brewers, and bakers (or the same ones with other resources) choose to follow a philanthropic path. These owners can set up private foundations and other forms of charitable entities that we call collectively philanthropic trusts. Such trusts are also immune from the RAP and hence can last forever. Like dynasty trusts, private philanthropic trusts create a usufruct. The charitable lead interest can make use of the principal, or endowment, but must preserve that endowment itself for later use or special circumstances. There is no jus abutendi over the wealth. As with dynasty trusts, philanthropic trusts now have massive wealth: there are over one trillion dollars in private foundations alone in America. ${ }^{103}$

These two kinds of potentially perpetual trusts now hold at least two trillion dollars of wealth. They result from individual butchers, brewers, and bakers responding to the incentives generated and rights allowed under the absolute property-tax bundle, both as to the creation and preservation of their capital in the first place and as to its transmission beyond their graves. They chose to leave their wealth in usufruct for their posterity, forever. We can learn from this.

Dynasty and philanthropic trusts are also creatures of tax law; they are property-tax bundles that come about when tax sets boundaries on what one can do with her money. A reasonable society can shape these -- can affect the property rights governing the assets in these trusts -- by changing the tax law, as the United States Supreme Court has done, for example, in constraining the

\footnotetext{
102 See Broadway Nat. Bank v. Adams, 133 Mass. 170 (1882)..

103 http://data.foundationcenter.org/
} 
definition of "charity" entitled to tax-favored status. ${ }^{104}$ This is society asserting its role in monitoring the appropriate use of capital.

\section{The Illustrative Case of Howard Hughes}

Howard Hughes was an iconic twentieth century American: brilliant pilot, movie director, inventor, more. Born wealthy in Texas, Hughes grew his fortune immensely; he was rumored at times to be the wealthiest man in the world, although mystery surrounded many facets of his life. ${ }^{105}$ Hughes was also a notorious recluse and eccentric. When he died in 1976 at the age of 70, Hughes left a fortune but no direct heirs and no Last Will. The ensuing disputes, called the "will contest of the century," actually straddled centuries, not fully coming to rest until well into the twenty-first. For a man who constantly employed clever and aggressive lawyers, accountants, and other professionals -- notwithstanding a decades-long avoidance of personal service to prevent appearing in any court proceeding -- the postmortem mess was striking. One would think that Hughes simply did not care about exercising his absolute power over his considerable wealth into infinite time.

One would be wrong. In 1953 Hughes had created a philanthropic foundation, the Howard Hughes Medical Institute (HHMI), to hold all of the stock of Hughes Aircraft Company. Hughes had founded Hughes Aircraft as a division of Hughes Tool Company, the company his father had founded in the early twentieth century. Howard Hughes Sr. had invented an oil drill bit that was so

\footnotetext{
${ }^{104}$ See Bob Jones University v. United States, 461 U.S. 574 (1983) (racist school policies violate definition of charitable entities under IRC \$501(c)(3))..

${ }^{105}$ My principal source for the material on Hughes discussed in this section is James Phelan's lengthy N.Y. Times Magazine article on Hughes from 1975. James B. Phelan, Howard Hughes, Beyond the Law, N.Y. Times Magazine, (Sept. 14, 1975); see also Gary Magnesen, INVESTIGATION: A FORMER FBI AGENT UNCOVERS THE TRUTH BEHIND HOWARD HUGHES, MELVIN DUMMAR AND THE MOST CONTESTED WILL IN AMERICAN HISTORY (2005); James Sterngold, 20 Years After Howard Hughes Died, His Empire Ends, N.Y. Times, (Feb. 23 1996); AP, 16 Cousins Declared Heirs to Hughes Estate, N.Y. Times (Aug. 11, 1981).
} 
far ahead of its time that the Hughes family became rich off of it. Both the elder Hughes and his wife died in 1924, leaving Howard an orphan at the age of 18. Hughes took over the tool company and went to Hollywood. Sometime after a near-fatal plane crash had started Hughes down the path of becoming a recluse, he founded HHMI in 1953 and gave all of the stock of Hughes Aircraft to it. One would think that Hughes had taken a philanthropic turn.

One would be wrong. As a private foundation, HHMI was indeed dedicated to doing good. But as a corporation, Hughes Aircraft was dedicated to making a profit. Hughes Aircraft acted like the orphan that Hughes was in fact, never paying its parent HHMI much. This is just as today, for tax reasons owing to Macomber's realization requirement, major corporations like Warren Buffet's Berkshire Hathaway or Jeff Bezos' Amazon do not pay dividends. Lawmakers raised questions about Hughes' structure for years. In 1969, Congress finally passed a major reform aimed at forcing philanthropic foundations to pay out a fixed percent of their assets' net worth, now five percent, for charitable and administrative purposes. ${ }^{106}$ Hughes was able to fight off the imposition of this rule in his lifetime, taking his complaints directly to President Richard Nixon along the way.

Hughes left no Last Will. But the heirless Hughes continued an extended battle until his death to preserve the structure of Hughes Aircraft, in essence an infinitely expanding money pump. Not until 1985, nearly a decade after Hughes' death, when HHMI was forced to sell Hughes Aircraft to General Motors in a transaction valued at $\$ 5.2$ billion, was the game over. "The sale, made in the wake of substantial tax questions raised by the Internal Revenue Service, will make the institute the largest private philanthropy in the world," the New York Times reported at the time. ${ }^{107}$ With an endowment over $\$ 23$ billion by the end of 2017 , HHMI is now the fifth largest philanthropic

\footnotetext{
106 James Phelan, supra note -.

107 Robert J. Cole, GM to Acquire Hughes Aircraft in a $\$ 5$ Billion Bid, N.Y. Times (June 6, 1985).
} 
foundation in the world, second in the United States only to the Bill and Melinda Gates Foundation.

108 Not bad for a man who died decades ago with no obvious heirs.

We see the role of social regulation in the HHMI story. Tax rules set the boundaries for what an owner can do with her money. Hughes was not a charitable man. He attempted to open a fourth path: an infinite business path. Hughes Aircraft could go on forever, retaining its profits, growing into a behmotheth, an ongoing testament to the extent of Hughes' present ownership powers. By imposing the five percent rule, the government constrained Hughes' ability to shape the use-rights of his capital through all time. The law, not his own benevolence, made Hughes a charitable man. Hughes can still leave his wealth to charity, escaping both tax and the RAP. But he must give the charitable interest the full use of the capital, the jus utendi et fruendi. The charity holds a usufruct.

The actual regulation of philanthropic trusts today goes beyond the five percent rule, with both various tax laws and regulations, as those against self-dealing, and state-law oversight of charitable activities. It is the concept of regulating property rights by tax that bears noting: tax laws create an incentive to pursue the philanthropic path but also shape the boundaries of that path. Note how this concept is almost altogether absent from the familial path, the domain of dynasty trusts. Tax creates the incentive to create dynasty trusts, but it places no meaningful limits on the private use of the capital within the trust. Other than requiring that no subsequent generation ever become the absolute owner of her wealth, the tax laws place no restrictions on how a present owner can direct the use of her wealth forever if she is keeping it in the family. This too will change under the fiduciary conception.

\footnotetext{
${ }^{108}$ https://en.wikipedia.org/wiki/List of wealthiest charitable foundations
} 


\section{Money under the Absolute Property-Tax Bundle: Cash as King}

The absolute property-tax conception has made many butchers, brewers, and bakers rich. Property theory, having neglected to develop any particular laws about the ownership of capital, gives each individual owner all of Pound's rights of property. Most strikingly, an absolute owner has an absolute right to waste. ${ }^{109}$ As Blackstone wrote:

[]f a man be the absolute tenant in fee-simple, without any incumbrance or charge on the premises, he may commit whatever waste his own indiscretion may prompt him to, without being impeachable or accountable for it to anyone $^{110}$

Under the absolute conception, not only is there no law against waste, there is an affirmative right to waste. An owner has the jus abutendi. This applies in full force to the use of money. One can do whatever one wants with the money in her pocket. Tax theory in its silo repeats the oversight. The American tax system lacks a systematic means to follow money and monitor its use. More generally, any source-based or prepaid tax lacks control mechanisms over the uses of wealth. This leaves us where we are. Many owners with excess capital and absolute rights over its use chose to pass wealth along the familial or philanthropic paths. But these are not their only choices. Any and all American billionaires can monetize their net worths, spend it all, and die broke, at any moment. Indeed, that is a tax efficient personal financial strategy.

\footnotetext{
109 On the right to waste generally, see Lior Strahilivetz, The Right to Destroy, 114 Yale Law Journal 781 (2005). Professor Strahilivetz's account, like that of Merrill and Smith, What Happened to Property in Law \& Economics, supra, is in rem. That is, he is concerned with the waste or destruction of things. Once again, this is orthogonal to the project of the property-tax bundle in this Article. For a view of the right to waste in the context of capital, see Edward J. McCaffery, Must We Have the Right to Waste?, in NEW ESSAYS ON THE LEGAL AND PHILOSOPHICAL UNDERSTANDING OF PROPERTY 76 (Stephen R. Munzer ed 2001).

${ }^{110}$ BLACKSTONE (1766) 3:223-24.,
} 


\section{Mayor Bloomberg and The Paradox of Death Taxation}

We use an example based on the actual case of Michael Bloomberg to illustrate the third path facing America's wealthiest as they ponder their personal mortality. Without passing any particular commentary of the social value of Bloomberg's self-financed presidential campaign, we do note that massive amounts of money in politics are certainly an example, perhaps the leading one, of how the private use of money can impose social harms. ${ }^{111}$

As noted above, wealth transfer taxes are rather easy to avoid. Billionaires motivated to pursue the familial path like Sheldon Adelson are able to do so, to the extent of billions of dollars, and their heirs are able to get the wealth and avoid all or most taxation for their lifetimes, ad infinitem using dynasty trusts. Thus the absolute property-tax bundle we consider features only a single, prepaid, wage tax. But both because it captures certain practical aspects of Mayor Bloomberg's marginal situation, and, more importantly, because it illustrates a paradox to explore within the absolute conception.

Michael Bloomberg is a former Mayor of New York City and was briefly a candidate for the Democratic nomination for President in 2020. He is also one of the world's ten wealthiest individuals, with a personal fortune in excess of $\$ 50$ billion, the round number we shall use in the example. At age 78, unmarried, having presumably used up his transfer-tax exemptions, Bloomberg faces three choices for what to do with his vast personal wealth. For simplicity, we assume that he will place all of his money on one of the paths, although of course he could pursue some of each.

111 See Edward J. McCaffery, A Better Hope for Campaign Finance Reform, ASU Law Rev. (forthcoming 2020); see also JANE MAYER, DARK MONEY: THE HIDDEN HISTORY OF THE BILLIONAIRES BEHIND THE RISE OF THE RADICAL RIGHT (2016); see also Dark Money, OPENSECRETS.ORG https://www.opensecrets.org/dark-money [https://perma.cc/8MDR-9GFS]. 
One, Bloomberg could give the $\$ 50$ billion to charity. Bloomberg in fact has committed to this philanthropic path, having signed the "giving pledge" along with fellow billionaires Bill Gates and Warren Buffet. The tax laws shape the potential beneficiaries of the wealth. These beneficiaries would get $\$ 2.5$ billion a year to use forever under the five percent rule were the capital to be held in trust or added to endowment.

Two, Bloomberg could pass the wealth along to his family or other named heirs. Under an effective estate tax as we posit for this section, the government would take $\$ 20$ billion, $40 \%$ of the capital, leaving $\$ 30$ billion to the heirs, who could thereafter live tax-free off the capital.

Three, Bloomberg could spend $\$ 50$ billion on personal whims and wants such as running for president. Having pledged to spend "whatever it takes" to defeat Donald Trump, Bloomberg actually spent just over $\$ 1$ billion on his abbreviated four-month campaign. ${ }^{12}$ The tax laws stood silent and the public got nothing directly from this personal expense.

We do not judge Mayor Bloomberg's choices. We could have chosen Jeff Bezos and his billion-dollar-a-year rocket ship hobby, Sheldon Adelson and his $\$ 100$ million every-two-years political contributions, or President Trump's lavish debt-financed and largely tax-free lifestyle to make an example. ${ }^{113}$ All these billionaires are doing what the law clearly allows them to do under the absolute property-tax bundle. This is the terms of the property-tax bundle America has set.

\footnotetext{
112 Seema Mehta, What You Need To Know About Michael Bloomberg—The Latest Billionaire Who Wants To Be President, L.A. TIMES (Nov. 26, 2019, 4:00 AM), https://www.latimes.com/politics/story/2019-11-26/bloomberg-self-funding-2020-presidential-campaign [https://perma.cc/TL9A-C4S3]; Shane Goldmacher, Michael Bloomberg Spent More Than \$900 Million on His Failed Presidential Run, N.Y. TIMES (Mar. 20, 2020), https://www.nytimes.com/2020/03/20/us/politics/bloomberg-campaign-900-million.htmln https://perma.cc/NMP6-CBDJ]. ${ }^{113} \mathrm{Id}$.
} 
What we can question, reimagine, and change is the choice set afforded our billionaires by the property-tax bundle. Table 1 sets out the relative share of Bloomberg's $\$ 50$ billion that the public would benefit from in the form of tax revenues (along the familial path) or dedication to charitable use (along the philanthropic path).

\begin{tabular}{|c|c|c|}
\hline Use & Private & Public \\
\hline Philanthropic & 0 & 50 \\
\hline Familial & 30 & 20 \\
\hline Personal & 50 & 0 \\
\hline
\end{tabular}

Table 1: Mayor Bloomberg’s Choices for $\$ 50$ billion, current law

In point of fact, given the generally ineffective estate tax that we have, the Familial row collapses with the Personal. Thus Table 1 can be restated to reflect the young billionaire's choices under the absolute conception: spend it all on oneself or give it all away.

The problem is manifest. Even if one has some "confined generosity," in Hume's turn of phrase, the temptation to spend some or all of one's wealth on oneself is great. Given that Bloomberg is committed to the philanthropic path, each dollar he spends on himself really costs him nothing on the margin -- the charity bears the expense. So too, any taxation along the familial path increases Bloomberg's marginal incentives to spend on himself versus leaving it for his heirs: he would be comparing a dollar spent on himself with sixty cents going to his heirs. This is a moral hazard problem -- precisely the moral hazard that led the common law to set aside the usufruct for 
absolute ownership. Hence the paradox of death taxation: Taxing the familial transmission of wealth risks increasing the waste of wealth by encouraging its imprudent use within an initial generation. ${ }^{114}$

${ }^{114}$ See Edward J. McCaffery, The Uneasy Case for Wealth Transfer Taxation, 104 YALE L.J. 283, 289-90 (1994). 


\section{A Fiduciary Property-Tax Bundle}

I set out on this ground, which I suppose to be self evident, 'that the earth belongs in usufruct to the living'....

Thomas Jefferson, Letter to James Madison (emphasis in original) ${ }^{115}$

\section{Property Concepts}

The absolute property-tax conception is so deeply a part of our American common sense, our "everyday libertarianism" in Murphy and Nagel's phrase, that it is hard to think about property any other way. It is simple enough, analytically, to change conceptions by adding, subtracting, or modifying rights in the property-tax bundle of rights. Practically, possibilities for alternatives abound; we can see them in our actual laws, past and present. Yet when we turn to consider any other particular conception, we struggle with unfamiliar ideas and alien vocabulary.

An exploration of this neglected intellectual terrain pays great dividends. We see aspects of an alternative property-tax bundle in some ways logically and chronologically prior to the absolute conception. This Article calls this conception the fiduciary property-tax bundle. It makes real -- a matter of the actual, positive law -- the metaphor of capital as a common pool of social resources. It closes the Lockean loophole for money by placing all wealth in usufruct for the living. Society can implement the fiduciary conception with modest changes to the tax component, once we have opened our minds to the possibilities.

${ }^{115}$ https://jeffersonpapers.princeton.edu/selected-documents/thomas-jefferson-james-madison 


\section{The Usufruct}

Instead of absolute ownership in time -- all six of Pound's rights of property -- the fiduciary owner has a usufruct. This is a strange term to modern ears, not found on any multistate bar exam. According to an online version of Black's Law Dictionary, "usufruct" means:

In the civil law. The right of enjoying a thing, the property of which is vested in another, and to draw from the same all the profit, utility, and advantage which it may produce, provided it be without altering the substance of the thing... . ${ }^{116}$

Under a usufruct, someone holds, manages, and reasonably uses property that belongs to someone else. The term never made its way formally into the English common law according to the Encyclopedia Britannica, ${ }^{117}$ and does not appear in the index to J. H. Baker's Introduction to English Legal History (third edition). It seems only to exist in America in any form in Louisiana and possibly Georgia. ${ }^{118}$

Yet Jefferson was not flippant in his word choice when he emphasized the "self-evident" truth "that the earth belongs in usufruct to the living." "Usufruct" has a precise meaning and boasts a lineage back to Roman law. Both the term and its associated conception were much in vogue among Enlightenment political theorists, including Filmer and Locke; Jefferson is essentially quoting Locke in his famous line. Pound, in his Ideal Element in Law, lists "the Roman standard of use by a

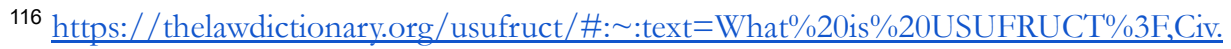

117 https://www.britannica.com/topic/usufruct

118 Louisiana recognizes life estates in usufruct under three circumstances; first, their intestate code (if you have parents and siblings but no descendants when you die, then your parents get it in usufruct and then your siblings get it. La. C.C. art. 891); second, it also arises under their community property doctrine, when one spouse dies the other gets their community property in usufruct (before it passes to their children. La. C.C. art. 890); third, it arises when a minor child inherits property, in which case the parent receives it in usufruct until they are of age.La. C.C. art. 616 kind of invalidates this with respect to the property, however, as it invalidates the usufruct on the property and converts it to the money or property received. In Georgia, land leased for less than 5 years is leased in usufruct.O.C.G.A. $\int 44-7-1$. 
prudent usufructuary" as one of several core doctrines in the law that "involve an idea of fairness or reasonableness;" others include the "standard of due care in the law of negligence, the standard of fair competition, [and] the standard of fair conduct of a fiduciary." 119 A commentary on Pound's essay explains that " $[t]$ he usufructuary is the person with the right to use, and Pound is indicating that there are obligations upon the usufructuary to protect the property for the ultimate benefit of the owner." 120

Perhaps most illuminating for our purposes is the etymology. "Usufruct" derives from the Latin usus and fructus, "use" and "enjoyment." 121 These are the participial forms of the verbal cognates whose gerunds Pound had used, utendi and fruendi, ("of using" and "of enjoying"). A usufruct, quite literally, consists of two of Pound's three use-rights. A usufructuary conserves, manages, and invests specific property for maximum value. She also holds the jus utendi and fruendi. She can use and reasonably enjoy the fruits of the property that she manages. But the usufructuary does not have the jus abutendi. She cannot misuse, abuse, or destroy the property; she has a fiduciary duty to maintain the value of the capital of the property for someone else. To Jefferson, this meant taking care of the physical property of the earth and preserving it for future generations, an ideal of environmental stewardship.

The usufruct was the initial model for ownership in Locke. Individuals did not have the jus abutendi in the state of nature because if they let fruit rot or animal carcasses putrefy, they not only

\footnotetext{
${ }^{119}$ ROSCOE POUND, THE IDEAL ELEMENT IN LAW, ed. Stephen Presser (Indianapolis: Liberty Fund 2002). 6/16/2020. https://oll.libertyfund.org/titles/671\#Pound 0094536

120 THE LEGAL GLOSSARY BY ROSCOE POUND, Liberty Fund, https://oll.libertyfund.org/pages/a-legal-glossary-by-roscoe-pound

${ }^{121}$ See NICHOLAS, AN INTRODUCTION TO ROMAN LAW, supra, at p. 154 (" $[\mathrm{t}]$ hus, the commentators adapted the definition of usufruct by adding to the rights of use and enjoyment the right of abuse - ius utendi fruendi abutendi. The adaptation is a little forced, since 'abuse' has to include alienation, but it is also, in its emphasis on the plenitude of enjoyment conferred by ownership, misleading..").
} 
sacrificed their property right but also became liable to be punished. Locke let down his guard when money came on stage, because the ability to sell or otherwise monetize one's possessions mitigated any reason to waste specific property, and Locke did not countenance the concept of the waste of capital itself. The only difference between a usufruct and absolute ownership is the right to waste, which the usufruct lacks.

Within a century of the Second Treatise, Blackstone had bought into the logic of the monetized economy. Blackstone swept aside the concept of a usufruct by page four of his second volume, on Property, "of the Rights of Things." A few paragraphs after his "sole and despotic" proclamation, in language that anticipates Coase: and Demsetz, Blackstone writes:

But no man would be at the trouble to provide either [habitations for shelter or raiments], so long as he had only an usufructuary property in them, which was to cease the instant that be quitted possession; if, as soon as he walked out of his tent, or pulled off his garment, the next stranger who came by would have a right to inhabit the one, and to wear the other. ${ }^{122}$

Blackstone sees, anticipating Demsetz, the dynamic mismanagement of an asset that comes from limited ownership, either in or through time. If one only has a usufruct or a life estate interest in things, what incentive does she have to build up the value of her property through all time? It is absolute property rights that give her the optimal incentive from a social point of view to maximize the value of the asset through all of time. This is the Coase Theorem. Thus again the central paradox arises: giving an owner the right to waste prevents waste. This is true both regarding present tense destruction, letting fruit rot, and the neglect of future value that Blackstone suggests; acts of commission and omission. The way to leave land for the living in usufruct is to give absolute ownership to individuals.

\footnotetext{
${ }^{122}$ BLACKSTONE, supra, at Book II, Chapter 1, p.4.
} 
But once again, this is true "of things." Giving individuals the right to consume, waste, or destroy all of the wealth they control, in an age in which some individuals control more wealth than most nations, does not seem to be a prudent way to preserve capital for others. Monetization helped things to escape the constrictures of usufruct. Under the fiduciary property-tax conception, the usufruct returns to put wealth itself back under social control.

\section{The Life Estate}

Once again, property needs a temporal dimension. The canonical term for the absolute conception is the fee simple absolute. For the fiduciary conception, it is the life estate.

A life estate is in many ways more intuitive than a fee simple absolute. The life estate holder owns her property for so long as she lives. On her death, the property passes to some now future interest, a named third-party remainder or a reversion to the original owner. In a typical dynasty trust structure, each generation after the Trustor's has a life estate. On the expiration of each life estate -- on the death of a later generation beneficiary -- the property reverts back to the initial Trustor, the terms of whose dynasty trust set the next life estate holder. No generation after the Trustor's ever has full, unfettered ownership of the capital.

Under American law, a life estate holder can sell any specific asset she holds. ${ }^{123}$ She has the jus disponendi over what she owns. But one can only sell what one owns. Thus the life estate holder can only transfer ownership of a specific asset for her, the life estate holder's, life. This creates in the new owner (the transferee) a life estate pur autre vie, a life estate "for [the term of] another's life." Life estates pur autre vie are a strange phenomenon to a people habituated to the absolute conception.

${ }^{123}$ White v Brown. 
They restrict alienability and hence the productive use of an asset in fact if not in law; one's ownership ceases when someone else, the original life estate holder, dies. This is impractical.

In the spirit of Coase, Property solves its own problems. Here, as often, trusts do the work. The trust form provides a mechanism whereby the value of property, its capital, can be held for the benefit of a life estate holder while the Trust itself, through a Trustee, can convey fee simple absolute title in any specific assets held by the Trust. If Ant's dynasty trust holds a farm worth $\$ 10$ million, the Trustee can sell the farm in fee simple, and invest the proceeds in a mix of stocks and bonds and real estate within the trust. The Trust continues to hold $\$ 10$ million of principal value. This separation of ownership from the control of capital enabled the elimination of the Rule against Perpetuities.

The fiduciary property-tax bundle follows the lead set by successful butchers, brewers, and bakers. It pulls the dynasty trust treatment forward in time to apply it to the initial owner's own generation, using the tax laws in place of private contractual terms. The first generation of wealthy individuals -- Ant's -- will have its wealth in tax-favored savings accounts, just like everyone else will. Each generation is taxed on reasonable use and prohibited from unreasonable use of its own capital; each generation with excess wealth must either leave it for others or give the bulk of it to the collective. The present owner is left with a life estate; she cannot invade the principal without good cause. This is in contrast to the absolute conception, under which entire generations can live tax-free off of inherited wealth passed to them tax-free, and any absolute owner can spend it all and die broke at any time. Under the fiduciary conception, there is no tyranny of the present. 


\section{Capital as Remainder}

Both the usufruct and life estate components of the fiduciary property-tax bundle require another property interest. Neither the usufructuary nor the life estate holder can waste or abuse the property; both must preserve it for someone else. What is this property and who else owns it? The answers are wealth and all of us. The fiduciary conception makes capital itself a common resource, just as Jefferson saw the earth.

The idea of the common pool of capital is generally sourced to Thomas Hobbes, writing roughly a century before Blackstone. Hobbes raised the idea just as we are doing, in the context of the timing of taxation. ${ }^{124}$ The Hobbesean argument is that citizens should be taxed on their spending, not their work or savings, because the latter represents contributions to a common pool of social capital whereas the former represents withdrawals from it. John Rawls echoed the reasoning centuries later by writing that a spending tax in ideal theory "is preferable to an income tax (of any kind) at the level of common sense precepts of justice, since it imposes a levy according to how much a person takes out of the common store of goods and not according to how much he contributes (assuming here that income is fairly earned)." ${ }^{125}$ The contemporary "ultra liberal" theorist Robrto Mangabiera Unger has seen the light. Unger supports a spending tax in part because it "turns taxation into the ally, rather than the enemy, of saving and investment," and also because "it applies to what a social democrat should most want to tax: the hierarchy of standards of living and the individual appropriation of social resources."126

\footnotetext{
${ }^{124}$ THOMAS HOBBES, LEVIATHAN. New York: Penguin Classics, 1985 (1651).

${ }^{125}$ RAWLS, A THEORY OF JUSTICE, supra at 278.

${ }^{126}$ ROBERTO MANGABIERA UNGER. WHAT SHOULD LEGAL ANALYSIS BECOME?. Supra note at 139 .
} 
In the silos of tax theory, the Hobbesean position has been criticized as under-theorized ${ }^{127}$ and as supporting proportionate taxation. ${ }^{128}$ But this Article is not about metaphors or welfare economics analysis. Property-tax bundles set the actual law. The fiduciary conception effects a commonality to the use of capital as we shall see more clearly below. This is not a matter of metaphor. A progressive spending tax actually makes capital a common resource, privately managed but collectively owned, by restricting the use-rights of the present private holders of wealth.

\section{The Battle of Co-Owners: Doctrines of Waste}

There are co-owners in time under the fiduciary conception, given the usufruct, and through time, given the life estate. We the people are the co-owner, and wealth itself is the property. Whenever there is more than one owner, the common law requires doctrines that adjudicate their potential conflicts. The law of nuisance does this for neighbors in physical space. The common law doctrine of waste prevents a present owner, such as a life estate, from harming the value of the remainder, capital itself under the fiduciary conception.

What the usufruct and life estate lack is the right to capital. The British legal theorist Anthony Honoré sees this right as one of the essential incidents of absolute ownership:

The right to the capital consists in the power to alienate the thing and the liberty to consume, waste or destroy the whole or part of it; clearly it has an important economic aspect. The latter liberty need not be regarded as unrestricted; but a general provision requiring things to be conserved in the public interest, so far as not consumed by use in the ordinary way, would perhaps be inconsistent with the liberal idea of ownership. ${ }^{129}$

\footnotetext{
${ }^{127}$ See Michael J. Boskin, Taxation, Saving and the Rate of Interest, 86 JPE 3 (1978).

${ }^{128}$ See Barbara H Fried, The Puzzling Case for Proportionate Taxation, 2 Chapman L. Rev. 157 (1999).

${ }^{129}$ Honore, supra.
} 
To move from a usufruct to absolute title, we need to give the present owner two powers. One is the "power to alienate the thing." This is Pound's jus disponendi as to the whole. The usufruct, like the life estate, could only convey a limited temporal term at best, such as the life estate pur autre vie, which is impracticable. Two is the "liberty to consume, waste or destroy the whole or part if it." This is Pound's jus abutendi. As with the introduction of money into Locke's story of property, we see a good effect (the jus disponendi as to the whole) and a potentially divergent one (the jus abutendi). As with Locke, we see Honore finessing the bad effect, the right to waste, because he, too, fails to see the problem of money, and fails to contemplate a reasonable alternative. The "do no harm" principle is at risk.

Without giving individuals a full jus disponendi, society runs the primary moral hazard risk of feudal forms, namely that an owner has an incentive to maximize the value of the property in her lifetime, even if that means neglecting its future value. This is a harmful tyranny of the present. A full jus disponendi solves that problem; Jefferson's concern over the misuse of land turns out to be largely misplaced under the absolute conception. The trick is to get a full jus disponendi without being harmed by the concomitant jus abutendi. Honoré notes but does not dwell on this puzzle for long. Like many other Anglo-American property theorists, Honore sees the jus abutendi as being inconsequential in fact:

Most people do not willfully destroy permanent assets; hence the power of alienation is the more important aspect of the owner's right to the capital of the thing owned. This comprises the power to alienate during life or on death, by way of sale, mortgage, gift or other mode, to alienate part of the thing and partially to alienate. 
Honore sees the jus disponendi as critically important and the jus abutendi as constrained in fact by self-interest. This leads him to cede to the absolute conception and the absolute right to waste. Self-interest provides the check on waste.

But like Locke and others before him, Honore does not confront the significance of widespread monetization. Ordinary people do not "wilfully destroy permanent assets" but they do spend all of their money and die broke. Because Honore does not see waste as much of a practical problem, he does not spend much time searching for a solution: "a general provision requiring things to be conserved in the public interest, so far as not consumed by use in the ordinary way, would perhaps be inconsistent with the liberal idea of ownership." Absolute ownership with its right to waste capital seems like the best of all possible worlds to prevent waste.

With our eyes on money, we cannot afford to be so cavalier. What people do with the things that they own is likely to help us all by increasing the wealth of the nation. What people do with the money in their pockets may not help us at all. Excessive private spending may well harm various projects of a reasonable democraic society. In a curious twist of fate, the dynasty trust form chosen by successful butchers, brewers, and bakers to host their own capital provides a critical insight to address Honore's angst. Given absolute powers over their wealth, family-minded millionaires and billionaires have chosen to place it in usufruct for their heirs. They do so using Trusts. The Trustee has the full jus disponendi over each specific asset. No one has the jus abutendi over the wealth itself. Honore's two components of the right to capital have been separated, and only the right to dispose of the whole endures.

The fiduciary conception applies this structure to all wealth, from a social point of view. The fiduciary property-tax bundle precisely ensures for capital what Honore was unable to imagine for 
property, a "general provision requiring things to be conserved in the public interest, so far as not consumed by use in the ordinary way." Tax provides the general law against waste of capital thus far found wanting in the common law imagination. ${ }^{130}$

\section{Tax Concepts}

The fiduciary property-tax bundle features a progressive postpaid or spending tax. This is simply anSee income tax with an unlimited deduction for savings. The rearranged Haig-Simons definition sets the analytic form: Consumption = Income - Savings. By systematically allowing a subtraction for savings we arrive at a consumption or spending tax. In part to benefit from a double entendre and to focus attention on the conceptual social spendthrift trust, we call such savings accounts USAs, for "unlimited savings accounts." This term comes from the Nunn-Domenici USA Tax of 1995, a legislative proposal for a progressive postpaid tax that made its way to the floor of the U.S. Congress. ${ }^{131}$

Every individual can contribute any amount to a USA at any time. She will get a deduction in the year of contribution and so will not be taxed at that time. If Ant earns $\$ 100,0000$ but saves $\$ 20,000$, she will be taxed on $\$ 80,000$ (I - S, or C), and be left with $\$ 20,000$ in her USA. Ant can invest this broadly within the rules and regulations of the USAs, which need only prohibit personal consumption inside the account. ${ }^{132}$ She pays tax when and if she withdraws from her USA or otherwise spends money on herself. As there is no wealth transfer tax under the fiduciary

\footnotetext{
130 The contemporary property scholar Richard Epstein uses much the same line of reasoning as Honore. See Richard Epstein, "Justice Across Generations," in PHILOSOPHY, POLITICS, AND SOCIETY, VOL. 6: JUSTICE BETWEEN AGE GROUPS AND GENERATIONS, ed. by Peter Laslett and James S Fishkin (1992).

${ }^{131}$ https://openscholarship.wustl.edu/mlw papers/137/

132 See McCaffery, A Better Hope for Campaign Finance Reform, supra.
} 
conception, Ant can transfer her USA in whole or in part to her children, or anyone, tax-free, at any time. The child or other beneficiary would step into Ant's shoes, paying tax on her own withdrawals, just as Ant would have done. Combined with the progressive rate structure further discussed below, this change alone creates the fiduciary property-tax bundle of rights.

\section{A Simple Source Neutrality}

Tax theorists have historically desired an income tax for its "source neutrality," aiming to get at "all incomes, from whatever source derived," in the language of the XVIth Amendment to the U.S. Constitution that enabled the modern income tax. Given the tax's failure to effectively tax capital, the yearning for source neutrality has been a pipe dream. Ironically, however, a postpaid consumption tax has a form of source neutrality that is appealing to a reasonable society seeking to regulate the social use of property: it taxes all personal spending, however financed. It does so quite generally by following the money.

William Andrews referred to the kind of postpaid tax in the fiduciary property-tax bundle as a "cash-flow" consumption tax because it consistently taxes money used on personal consumption. 133 Consider again the general form of the postpaid tax, from the rearranged Haig-Simons definition, Consumption $=$ Income - Savings. The tax is meant to tax consumption, all consumption, and only consumption, all without regard to source. In its ordinary operations, it does so. Consider four possible means of Grasshopper's paying for a $\$ 10,000$ personal expenditure such as a nice vacation.

One, the money could come from current period wages, as it does for most Americans who do not save, living paycheck-to-paycheck. Grasshopper has income from wages, I, with no

\footnotetext{
${ }^{133}$ William D. Andrews, A Consumption-Type or Cash Flow Personal Income Tax, 87 HARV. L. REV. 1113 (1974).
} 
subtraction for savings, so his expense is taxed. Wages equal spending $(I=C)$, for those who do not save.

Two, Grasshopper could withdraw the money from his USA if he has saved. This would be taxed as negative savings (-S). Subtracting a negative leads to a positive, so we again tax the expense.

Three, Grasshopper could borrow, as on a credit card. This too is negative savings (-S). Subtracting a negative still leads to a positive, and again we tax the consumption. This treatment of debt may sound odd, but note that it is what happens when you pay for a good on a credit card subject to a sales tax; you pay the sales tax when you spend, even on borrowed funds, and then not again when you pay off your debt.

Four, Grasshopper could have gotten the money as a gift from his friend Ant. Here we either tax Ant, by denying her a deduction for making the gift (considering it her consumption), or Grasshopper, by making him treat the gift as income which he does not save. Either way we tax the expense.

In sum, a consistent postpaid tax gives society a means that the common law never thought it needed, and a corrective to a major error in income tax law: A tool to follow the money. All personal spending is taxed, however financed. There is no need under a consistent spending tax for capital gains preferences or any other source-based feature of tax.

\section{Changing the Rate Structure}

The final variable is to choose a rate structure to set the terms of the fiduciary property-tax bundle. This is a critical task for a reasonable society. Table 2 provides a simple marginal rate structure to illustrate the principal analytic elements of the fiduciary conception. 
Table 2 has just three rate levels. For all spending below $\$ 1,000,000$ a year -- for more than $99 \%$ of Americans -- there is a flat 30\% rate. It would be easy to create an effective "zero bracket" in this range by giving all individuals a cash grant, such as Andrew Yang's "universal basic income" idea. ${ }^{134}$ If each individual receives $\$ 1,000$ a month from the government, $\$ 12,000$ a year, this would offset taxes due on the first $\$ 40,000$ of consumption $(40,000 \times 30 \%=12,000)$ netting out to a zero tax-and-transfer rate over that range. That is a detail. An analytic fact is that a conversion to a consistent postpaid tax need not mean all that much for most Americans, who pay an average federal tax just over $30 \%$ on their wages. The changes occur among the rich, who control a disproportionate share of the nation's capital. The fiduciary conception is about the ownership of wealth, so it naturally applies with most force to those who hold wealth.

\begin{tabular}{|c|c|}
\hline Annual Spending Level & Tax Rate \\
\hline Under $\$ 1,000,000$ & $30 \%$ \\
\hline Over $\$ 1,000,000$ & $50 \%$ \\
\hline Over $\$ 50,000,000$ & $90 \%$ \\
\hline
\end{tabular}

Table 2: Progressive Spending Tax Rates

Table 2 adds two higher marginal rate brackets. The rate increases to $50 \%$ at over one million dollars $(\$ 1,000,000)$ of spending per year. This rate is higher than the top rate on the income tax today, 37\%, but well in line with historic averages. Finally, and again to help make analytic points, the marginal rate increases to $90 \%$ for spending over $\$ 50$ million a year. Few would be in this bracket, which is set to reflect a billionaire's spending levels, but it plays an important role in the

\footnotetext{
${ }^{134}$ See Matt Stevens and Isabella Grullon Paz, Andrew Yang's \$1,000-a-Month Idea May Have Seemed Absurd Before. Not Now., N.Y. Times, Mar. 18, 2020.
} 
conception. America had a top marginal rate under the income tax of $90 \%$ or higher for two decades, from 1944 until 1964. It is also a marginal tax rate that many working poor in America face because of the phaseouts of their benefits as well as taxes. ${ }^{135}$ That is a story for another day.

\section{Connecting the Timing and Rate Structure of Tax}

We can now more fully consider the linkage between the two elements of the tax component of the property-tax bundle, its timing and rate structure. It is not random that the absolute conception features a prepaid tax with flattened rates while the fiduciary conception has a postpaid tax with steeply progressive rates at its upper ranges. Rate structures are interdependent with the choice of timing of tax.

Under the absolute conception with its prepaid, wage-based tax, a marginal tax rate as high as $90 \%$ seems like a confiscation to everyday libertarians. One's only choice to avoid the tax is not to work. A reasonable society might worry about the incentives generated by such a property-tax bundle: It puts a great deal of weight on the benevolence of butchers, brewers, and bakers because it asks them to continue to work with little reward. Optimal income tax theory, a highly mathematized version of the utilitarian tradition of which Smith was a forbearer, does not feature high marginal tax rates. ${ }^{136}$ Nor does a marginal rate as high as $90 \%$ seem fair or appropriate from a moral entitlement, Lockean perspective. Why is an individual less entitled to the produce of her own labor on account of the fact that others -- impersonal market forces -- value them more highly? High wage tax rates risk divergence between the private and public: the worker may stay home at the margin, sacrificing the wealth of the nation to her tastes for leisure. In fact, the high marginal tax

\footnotetext{
${ }^{135}$ See Edward J. McCaffery, America's 90\% Tax Rate, CNN (Feb. 2013).

${ }^{136}$ See Mirrlees, supra note -.
} 
rates we have seen under the income tax have been symbolic: by manipulating their affairs within the definition of "income," the rich have avoided them.

Progressive rates under a postpaid tax are different, conceptually and in fact. The wealth sits in USAs, not yet taxed. It will not be taxed until and unless it is converted into personal consumption. The rich will no longer be able to spend all of their vast wealth on themselves. Since a postpaid tax falls on spending, all spending, and only spending, it is harder to avoid: it is difficult to conceal a $\$ 1,000,000,000$ presidential run or trips to the moon. But the wealthy have other choices than to spend on themselves. Under the fiduciary conception, they are allowed to continue to manage and control their wealth. The philanthropic path for its use is still open. The familial path is also still open, with the background basic tax law now effecting a usufructure for each successive generation just as the initial owner faces. Only the personal path has been constricted, by applying the same use-restriction within as across generations., eliminating the right to waste. There is reason to believe -- from observed reality -- that this is a structure that reasonable butchers, brewers, and bakers would accept ex ante.

\section{A Social Spendthrift Trust}

The fiduciary property-tax bundle allows us to restate Jefferson: All wealth belongs in usufruct to the living. Society obtains this end by placing all wealth in trust, the tax-favored savings accounts. Taxes are paid on the use of wealth. Tax rates have been set such that individuals can use but not abuse capital. By the time individuals become extremely wealthy, they are primarily fiduciaries over their wealth for others, because they cannot use the capital on the margin for their personal pleasures. As a conceptual matter, the fiduciary bundle invites us to think about capital in a different 
way from our absolute habits of mind. Wealth belongs to the living in usufruct, and to us all in remainder.

As with all analytic descriptions, conceptual understandings are matters of language, of how we look at things. But how we look at things matters. Conceptions describe legal realities. "Sole and despotic dominion" is a metaphor whose aptness we might debate; a fee simple absolute owner's ability to convey property free of any future interest is a legal fact. Calling a property system with a progressive spending tax a social spendthrift trust is a matter of language. Not being able to “consume, waste, or destroy" all of one's wealth on oneself is a legal fact.

Consider society's aggregate capital stock, its sum total of unspent private wealth, under the fiduciary property-tax bundle. All private wealth is in yet untaxed USAs. Note by the way that this happens automatically for specific assets, without the need to formally place them into a trust; within tax law, the trust can be a metaphor. Suppose for example that Ant holds an asset, a farm or some corporate stock, worth $\$ 10,000$. She holds this asset outside of any formal USA; perhaps she owned it prior to the enactment of the new postpaid tax. If Ant were to sell the asset or borrow against its value and spend the proceeds, she would be taxed under the consistent spending tax. If she were to sell the asset and reinvest the proceeds, she would not be taxed. All consumption is taxed and no savings is. No formal accountings are needed. Once Ant is already spending at the level of $\$ 50$ million a year, any additional use of her wealth in any form for personal pleasure will bear the brunt of the $90 \%$ tax. We can see that all wealth is conceptually in a spendthrift trust, subject to the social tax rates on use.

Ant can now store up any wealth that she does not use for immediate consumption -- that is, her nonconsumption or savings -- in the global spendthrift trust. Society will not charge its share 
(the baseline wage tax) but instead will allow Ant to manage that share in usufruct. Ant can withdraw from the trust for her needs and reasonable wants at no net charge over the baseline tax, remitting the government's share at the moment of conversion to personal use. While in trust, both the private and public shares increase apace. If Ant is fortunate enough to own wealth beyond what is needed to finance a reasonable lifestyle -- as determined by the reasonable society itself, in the exercise of its public reason -- she no longer can use the capital on herself. She can continue to be Trustee and income beneficiary, but she no longer has access to the principal for personal consumption.

\section{Capital for the Ordinary Citizen}

For almost all Americans in our illustrative example, the tax on use is set at $30 \%$, roughly the average tax burden on workers today. As with all aspects of the property-tax bundle, there are different ways to look at the legal reality.

One way is from the individual's point of view. For ordinary citizens, the USA is a simple vehicle to save for retirement and urgent needs. There are no rules about maximum or minimum contributions or mandatory withdrawals. As noted above, there is not even a need to formally place specific assets into a literal trust: only spending, not savings, is taxed as a matter of law. To underscore the parallel to a spendthrift trust, the tax law could impose lower or even no positive rate on withdrawals from USAs -- on any spending -- for certain specified uses, such as for health, education, and maintenance, as in the HEMS standard discussed above (the element of support could be accounted for by the universal basic income grant). When the owner goes to use her capital, she must first remit the $30 \%$ share she has held in usufruct. As we saw above, this is 
analytically equivalent to a flat wage tax that includes capital windfalls; there is no net tax on the ordinary use of capital markets to finance ordinary lifestyles.

A second way to view the spendthrift trust is from the social point of view. Under the fiduciary conception, society owns the capital stock. Society charges labor 30\% as the reasonable price of civilization. For those who do not want or need to consume all that they earn, society offers free access to the capital markets. It does not collect its 30\% share upfront but allows the individual to hold that share in usufruct. The private and the public become partners in the financial markets.

Suppose that Ant, having met her basic needs and wants out of her salary, has $\$ 10,000$ left over to save. Under the absolute conception, which taxes wages and only wages, Ant must still pay $30 \%$ in taxes on the $\$ 10,000$. She has no deduction for savings. But she will never again be taxed on the $\$ 7,000$ residual after taxes, her "net income." This $\$ 7,000$ can grow, tax-free inside a Roth account or otherwise, and the game can go on for generations, financing a tax-free lifestyle for Ant's heirs should she so please. Ant owns the capital absolutely. She and her heirs benefit exclusively from any windfall gains and have the right to waste all their share of the wealth at any time.

Under the fiduciary conception, Ant does not now pay tax on the $\$ 10,000$. She can invest this full amount in her USA. Ant is now managing wealth for both herself and the government. In addition to her own, 70\%, share, Ant is investing the government's 30\% share for all. Suppose Ant invests well and the $\$ 10,000$ doubles, to $\$ 20,000$, at which time she decides to pull all of her money out to spend. The government takes its $30 \%$ share, $\$ 6,000$. We can see that the initial $\$ 10,000$ consists of a $\$ 7,000$ "private" and a $\$ 3,000$ "public" share. Both shares double; the private going to $\$ 14,000$ and the public going to $\$ 6000$. The government has let Ant, who has shown herself to be a frugal capitalist, do the investing for it. This is a repeat of the basic butcher, brewer, baker script. Just 
as the government is depending on Ant's labor to fuel the wealth of the nation, so is the government a silent partner in Ant's capital market activities.

As to this 30\% share, Ant has become a fiduciary. She holds it in usufruct. Her gains are our gains. Whenever and however Ant or any of her heirs moves to convert capital to personal use, the government appears to take its 30\% share back. The reasonable society has trusted Ant with the task of managing wealth until that time not on account of naive belief in her benevolence. It has done so because the $70 \%$ share of Ant's USA that she has for personal use provides ample self-interest to motivate her to invest well. As for that $70 \%$ private share, Ant has been allowed to use the capital markets at no net charge. She owned the $\$ 7,000$ after earning the money, and that share has been allowed to double without any further tax. John Stuart Mill would approve. Citizens living reasonable lifestyles, within the range of the tax's lower rates, do not pay a charge for using capital because they are not abusing capital. Society has set a level of usus and fructus at which all can use capital for no extra charge.

\section{Capital for the Aristocrat}

Table 2 sets a $50 \%$ rate on personal spending over $\$ 1$ million a year. If we were to capitalize the amount of wealth needed to support such a personal lifestyle, at the five percent rate from the Howard Hughes example, we would need more than twenty million dollars. Twenty million dollars of net worth is higher than the current wealth level of the top one percent of Americans, \$10.4 million; this top percent controls $30-40 \%$ of Americans' $\$ 100$ trillion aggregate net worth. ${ }^{137}$

137

https://alfred.stlouisfed.org/series?seid=WFRBST01134\&utm source= series page\&utm medium=related content\&utm term $=$ related resources\&utm campaign=alfred

https://www.wsj.com/articles/u-s-net-worth-surpasses-100-trillion-1528387386 
Roughly speaking, then, about one-half of one percent of Americans could be consistently spending in the posited $50 \%$ rate bracke. This group controls perhaps $\$ 30$ trillion of wealth. This is more than the aggregate wealth of any nation on earth except for the United States (of which it is a subset) and China. ${ }^{138}$ We call them Aristocrats.

If some butcher, brewer, or baker were spending as if they were an aristocrat -- more than $\$ 1,000,000$ a year of spending but less than $\$ 20$ million of capital -- he too would be faced with the $50 \%$ tax on his marginal spending, and nudged back down to the ranks of "ordinary" spenders soon enough. This is another feature of the conceptual spendthrift trust; owners are punished for spending beyond their means, using too much of their capital in the present, and encouraged to be frugal as they become wealthier. It takes more than twenty million dollars of capital to sustain a million-dollar-a-year lifestyle over an extended period of time. Once an Aristocrat is spending that much, she becomes a co-owner of the use rights over "her" capital. If a particular Aristocrat wants to spend an additional $\$ 100,000$ on a luxury car, for example, she must withdraw $\$ 200,000$ from her USA, paying one-half, or $\$ 100,000$ to the collective to enable her private spending. Once more, it does not matter if Aristocrat pays the expense any other way, as out of current period labor earnings or debt; she will still have to pay $\$ 100,000$ in taxes, a matching amount, for the privilege of living so well..

From the social point of view, the literal usufruct has increased. Aristocrat still has all of the control rights over her wealth, but she can only use one-half of the capital on personal consumption. She holds one-half of her capital in usufruct. She cannot "consume, waste or destroy" all of her

138 https://en.wikipedia.org/wiki/List of countries by total wealth 
money. If Aristocrat were to withdraw $\$ 20$ million for one grand final binge, the government would immediately take $\$ 10$ million of it. ${ }^{139}$ Aristocrats lack the jus abutendi over all their wealth.

\section{Capital for the Plutocrat}

The final rate bracket in Table 1, again illustrative, is $\$ 50$ million. This is the five percent annuity amount for a wealth level of one billion dollars $(\$ 1,000,000,000)$. Again this is a small number of people who control a great deal of wealth. Piketty's colleagues Emmanuel Saez and Gabriel Zucman calculated that in 2012 the top 0.01 percent had an average wealth of $\$ 371$ million, and a total wealth of $\$ 6$ trillion. That same year the estimated combined net worth of the individuals

on the Forbes 400 list was $\$ 1.7$ trillion. ${ }^{140}$ By 2020 there were over 600 billionaires in the United States, and their collective holdings were roughly $\$ 3$ trillion $(\$ 3,000,000,000,000) .{ }^{141}$ We call them Plutocrats.

For Plutocrats in the $90 \%$ marginal tax rate bracket, things change dramatically under the fiduciary conception. In these ranges of wealth, the Plutocrat continues to manage her wealth, but she cannot use it on herself without incurring a 90\% tax. She has become a fiduciary, managing capital for others, holding ninety percent of her wealth in usufruct. Each Plutocrat still has a philanthropic and a familial path available to her, but she cannot spend the money on herself, now.

\footnotetext{
139 The points in this paragraph are stronger at a 70\% marginal tax rate of course. At such a rate, Aristocrat can only spend $\$ 6$ million out of $\$ 20$ million; she would have to pay the government $\$ 14$ million. We explore the dynamics in the $90 \%$ example below. 140 https://review.chicagobooth.edu/economics/2017/article/never-mind-1-percent-lets-talk-about-001-percent 141

$<<$ https://philanthropynewsdigest.org/news/u.s.-billionaires-wealth-up-434-billion-during-pandemic-study-fi $\underline{\text { nds }}>>$
} 
Plutocrat must save her fortune for others and for a later day, or give the bulk of it to the collective, retaining a $10 \%$ commission for having managed it in the meantime. We pick up these themes when we revisit the financial situation of Mayor Bloomberg, below.

\section{From the Sovereign's Side}

Conceptions affect how we imagine and understand reality. Moving from an absolute to a fiduciary conception involves an analytically simple change to tax and the mere elimination of the jus abutendi from Pound's bundle of rights. This is nonetheless a Copernican revolution in our understanding. It shifts the center of our conceptual universe. The absolute conception placed private individuals and private property at the center of the story, with society as satellite to gain, parasitically, from private productive activity. The fiduciary conception places society back at the center as owner of all wealth. Capital is a social construction. We consider what a reasonable state might do, given the brute fact that it establishes and thus controls capital markets in the first instance.

Under the fiduciary conception, all capital is held in a common pool. The sovereign allows most citizens to partake of the pool free of net charge, even deferring its baseline $30 \%$ charge for unconsumed wages. All capital is managed privately. At any time, most ordinary individuals can spend down their wealth simply by giving back the 30\% share they have held in usufruct. But as various butchers, brewers, and bakers succeed and build up wealth, beyond their needs and reasonable wants, within and across generations, things change. The right of the individual to draw down capital for personal pleasures decreases, and the share held in usufruct increases, until, at the highest levels of wealth, the capital is primarily social. Plutocrats must keep their wealth in the 
common pool or give it to the collective in the form of taxes. And while we can generally trust self-interest to make these billionaires good fiduciaries over this common pool, the law can protect its ownership interest by loose regulations over the usufruct, just as the law now imposes the five percent rule on those choosing the philanthropic path.

\section{Money under the Fiduciary Property-Tax Bundle: Cash, Constrained}

Under the absolute conception, owners can monetize all of their wealth, spend all of the money in their pockets, and die broke without question or taxes. The fiduciary property-tax bundle radically changes this. By changing the property-tax bundle, society has altered the paths available to its most successful butchers, brewers, and bakers. It has reigned in the power of money.

\section{Revisiting Mayor Bloomberg}

Under current law Mayor Bloomberg can spend $\$ 50$ billion on himself, as by running for president. No tax and no regulation stands in his way. If Bloomberg is inclined to keep money within his family and friends, he can now give $\$ 30$ billion to heirs who would have to pay $\$ 20$ billion in taxes to the collective. Or he can, as he has in fact pledged to do, give the $\$ 50$ billion to charity following the rules and regulations laid down by the government for the philanthropic path. Table 1 above set out how Bloomberg's $\$ 50$ billion would be shared between private and public use. In fact, had Bloomberg been so inclined, he could have (and perhaps did) get far more wealth to his children, tax free. To plutocrats like Sheldon Adelson -- all those who are not "morons" under Gary Cohen's definition -- the personal and familial paths look the same. Neither incurs a tax. Under today's laws, Mayor Bloomberg's choices are either to give money to charity or to spend it on himself and within his family. Any actual taxes in Bloomberg's story are voluntary under today's law. 
Under the fiduciary conception, Bloomberg cannot now spend the $\$ 50$ billion on himself. Were he to try, he would immediately incur a $90 \%$ tax and have to pay $\$ 45$ billion to the government in taxes, leaving $\$ 5$ billion for himself. The personal path is highly constricted; most of the wealth is held in usufruct. The same result obtains along the familial path. Bloomberg can pass his wealth to his heirs without a wealth transfer tax under the fiduciary conception, because the Bloomberg family is continuing the usufruct. Bloomberg's heirs face the same use-restrictions in the tax laws as he does.

Suppose that Bloomberg has five heirs. Each would inherit $\$ 10$ billion, tax free, under the fiduciary conception. But each heir can then spend "only" \$1 million each year without facing the higher rates of the progressive spending tax. Within the rate brackets we are using, no heir could spend more than $\$ 50$ million on herself without being in the $90 \%$ rate bracket; this is the aristocratic life estate of a billionaire. (Once one has one billion dollars, she can "only" spend 5\% of her wealth until she is in the $90 \%$ bracket). After any heir had spent $\$ 50$ million in a year, if she went to spend all that she could, the government would take nearly $\$ 9$ billion of the wealth back. Each generation, all individuals, hold excess capital in usufruct.

This is an important distinction between the conceptions. Under the absolute conceptions, heirs can live tax-free because taxes are based on labor and the descendants of billionaires do not have to work for wages. Under the fiduciary conception, the heirs are taxed just like everyone else, and if their access to wealth allows them to live at a high level, they too are made into fiduciaries. Table 3 sets out the revised figures, collapsing the personal and familial paths as just discussed. 


\begin{tabular}{|c|c|c|}
\hline Use & Private & Public \\
\hline Philanthropic & 0 & 50 \\
\hline Familial and Personal & $5^{*}$ & 45 \\
\hline
\end{tabular}

Table 3: Choices for Spending $\$ 50$ billion, fiduciary conception

The differences between Tables 1 and 3 are of course radical. The temptation for billionaires under the absolute conception to buy baubles and beads is immense. We ask our wealthiest fellow citizens to compare a dollar spent on themselves with less than a dollar given to distant heirs or the same dollar given to remote public beneficiaries under stringent legal guidelines. We are putting ever growing weight on the benevolence of billionaires while holding society hostage to their continued restraint. Under the fiduciary conception, we remove the temptation to personal lavishness, within and across generations, while providing as a continued incentive that a good many billionaires, to our collective good fortune, are pursuing on their own. 


\section{Reimagining Property}

[1]t is said that hunger and poverty make men industrious, and that laws make them good.

Niccolo Machiavelli, Discourses on Livy, Book 1, Discourse 3

Now everyone recognizes that the institutional form of society affects its members and determines in large part the kinds of persons they want to be as well as the kind of persons they are.

John Rawls, Political Liberalism, Lecture VII, \5

We have been on an intellectual journey, following the Western liberal property theory tradition from Roman times and usufructs through Hobbes and common pools of capital. We arrived at Locke, and saw that he was not willing to give individuals absolute property rights in the state of nature. He was concerned about the potential waste and misuse of particular assets like fruit and land. Property was held in usufruct. But Locke concluded that money could not spoil, and he had no problem extending the conception of private ownership to it. By the time of Blackstone, virtually all constraints on ownership under property law had faded. The absolute conception was ascendant, given full form in Blackstone's "sole and despotic dominion" conception. Smith saw that harmony could be obtained between the private and public sectors by giving butchers, brewers, and bakers private property to trade in private markets. America was born into the absolute property-tax conception.

The conception worked wonderfully well in the nineteenth century towards its intended end. The wealth of the nation vastly increased. By the early twentieth century, America was fully 
participating in a golden age of capitalism, La Belle Epoque on the Continent and a Gilded Age here, as Thomas Piketty's work details.

But absolute private property also produced a great deal of inequality. Wealth has never been especially equally held, in any society. ${ }^{142}$ The West in the Belle Epoque and America today are especially unequal in this regard. And the wealthy had then and have now absolute power over their wealth, including the right to waste it. Social harmony depends, perilously, on the benevolence of billionaires.

\section{A Twentieth Century Conversation}

The Belle Epoque ended in great wars and other social and economic catastrophes, giving pause to liberal political theorists. We pick up the conversation at this point, with a prominent political theorist of the second half of the twentieth century, John Rawls, commenting on the analysis of a prominent political economist of the first half of the century, John Maynard Keynes. Here is Rawls, in A Theory of Justice from 1971, discussing a passage in Keynes' Economic Consequences of the Peace from 1920:

Keynes remarks, for example, that the immense accumulations of capital built up before the First World War could never have come about in a society in which wealth was equally divided. Society in the nineteenth century, he says, was arranged so as to place the increased income in the hands of those least likely to consume it. The new rich were not brought up to large expenditures and preferred to the enjoyments of immediate consumption the power which investment gave. It was precisely the inequality of the distribution of wealth which made possible the rapid build-up of capital and the more or less steady improvement in the general standard of living of everyone. $^{143}$

\footnotetext{
142 PIKKETY, supra note -.

${ }^{143}$ RAWLS (1971) 298-99, citing KEYNES (1920).
} 
Keynes is a product of the absolute conception. He saw that Smith's butchers, brewers, and bakers had started to amass great wealth by the end of the nineteenth century, "before the First World War.'. But they had not started to spend it much: they were acting like fiduciaries, treating the wealth as a usufruct. They were "not brought up to large expenditures" and preferred "the power which investment gave" to "the enjoyments of immediate consumption." These particular butcher, brewers, and bakers produced a net good world, according to Keynes. Rawls does not disagree.

What Rawls questions is the practicality and stability of the situation, seeing that it depends on unchecked human behavior:

If the rich had spent their new wealth on themselves, such a regime would have been rejected as intolerable. Certainly there are more efficient and just ways of raising the level of well-being and culture than that Keynes describes. It is only in special circumstances, including the frugality of the capitalist class as opposed to the self-indulgence of the aristocracy, that a society should obtain investment funds by endowing the rich with more than they feel they can decently spend on themselves. (emphasis supplied). ${ }^{144}$

Rawls sees that only the "special circumstances" of the "frugality of the capital class" can normatively justify what seems to be a near universal fact of human society: the unequal possession of wealth. Rawls worries that these circumstances are merely a matter of fortuity and benevolence. "If the rich had spent their new wealth on themselves, such a regime would have been rejected as intolerable." Frugality can easily turn into "self-indulgence of the aristocracy" as circumstances change. Under the absolute property-tax bundle, plutocrats can spend all of their wealth on themselves, at any time. That is a problem.

${ }^{144}$ RAWLS (1971) at 299. 
What Rawls misses is that society sets the circumstances for the use of wealth; there need be nothing "special" about them at all. The understandings gleaned from the concept of the property-tax bundle advance the conversation. The unequal accumulations of capital Keynes notes are byproducts of the absolute conception. Under this conception, Keynes sees that, as a matter of fact, the capitalists acted like usufructuaries. Rawls is correct that nothing legally stands in the way of the rich spending "their new wealth on themselves." What neither thinker imagines is a reconception of the property-tax bundle such that the rich cannot spend their wealth on themselves and have to hold it for others. Rawls assumes without noting any specifics that "certainly there are more efficient and just ways of raising the level of well-being and culture" than "endowing the rich with more than they feel they can decently spend on themselves." But half a century after Rawls wrote these words, we find ourselves in the midst of a next Gilded Age, with possible similar social cataclysms to come, still clinging to the absolute conception. Western capitalist societies continue to produce vast amounts of wealth, unequally held .

History suggests that this unequal possession of wealth is likely if not inevitable in a capitalist economy. If a society is going to get wealthy by sending forth its butchers, brewers, and bakers to build up the wealth of the nation for it, it should reasonably expect that some but not all of these individuals will succeed, some but not all will save, some but not all will invest well, and some but not all will contemplate what to do with their capital from beyond the grave. A reasonable society may not want to extract a progressive share from the sources of such wealth, for to do so is inconsistent with the goal of building up that wealth itself. We cannot be too progressive under a wage tax without cutting off our nose to spite our face. But a reasonable society can control the uses of wealth. 
The fiduciary conception takes a different approach. It allows for the private generation of wealth, in labor and capital markets. It taxes uses and only uses. In doing so, it changes property rights. The highest tax bracket takes away the jus abutendi over the wealth of plutocrats. This creates a usufruct. Successful butchers, brewers, and bakers can still be motivated by the "power that investment brings," or by love of their family and descendants, or by philanthropy. History suggests that many perhaps most wealthy people are so motivated: these are traits and motivations that help people to become wealthy in the first place. Whether brought up to it or not, the rich can no longer spend all of their wealth on themselves. Wealth, like Jefferson's earth, is now held in usufruct, and must be preserved for the good of all.

\section{Back to the Beginning: Capital and Labor Strike a Deal}

As one final perceptual frame to help understand the concept of the property-tax bundle and its power, we go back to the start, to the original terms of the social contract. Imagine that representatives of a reasonable society, on behalf of Capital, the inchoate wealth of the nation, meet with representatives of butchers, brewers, and bakers, representing inchoate Labor. The state is about to be formed and it would like to maximize its wealth. We are in a stylized allegory of America's founding, with knowledge of contemporary capital markets and tax systems. This is a common general form of business negotiations today, where one partner offers capital and another labor, and the two hash out their shares. These shares often shift as certain benchmarks or levels are met.

Capital, the government, the wealth of the nation, will provide a range of public goods, including national defense, domestic security, public health and education, roads, parks, and so on. 
The state will also form and support capital and monetary markets. Capital and Labor will negotiate a property-tax bundle. .

Under the absolute conception, the deal is that the state takes a share of labor efforts, say $35 \%$. (The rough instinct is that a single flat rate on labor efforts needs to be higher than the lowest rate under a progressive spending tax, to make the aggregate yields equal.) Individuals can then use the capital markets free of charge, for generations. That outcome is possible today. Allowing wealth to build up across generations without tax when capital is systematically outperforming growth, as Piketty's work shows, is a recipe for ever-expanding inequality.

Under the fiduciary conception, the deal is that the state takes a share of spending. There is a $30 \%$ rate up to a $\$ 1,000,000$ level of annual personal consumption. Over this range, the tax is equivalent to a flat 30\% wage tax. If individuals just work and spend, they pay their 30\% share. But if some individuals have more wealth than they consume for needs and reasonable wants in any year, they can save. The government does not collect its 30\% share, but allows the individual to save in a USA. Within that account, at all times, the private owner holds the $30 \%$ share in usufruct. Her $70 \%$ ownership of her own share grows equally with the government' $30 \%$ share. That share increases for successful butchers, brewers, and bakers. In our running example, the rate and share go up to $50 \%$ at a million dollars a year of spending, and to $90 \%$ at a billionaire's level.

The representatives of Capital might point out that those individuals who can live so well have benefited most from the capital markets. They can say that the taxation of some capital makes it possible to lower the rates on labor to better enable individuals to build up financial wealth in the first place. The deal is attractive to reasonable butchers, brewers and bakers too. Like Smith, we have developed the conception in part by considering what people actually do in regard to their own 
self-interest. History has taught us that plutocrats are content to amass great fortunes and to pass them on, philanthropically and/or within the family. The fiduciary conception allows them to do just that, maintaining a harmony between private and public throughout, by operation of law.

The fiduciary conception takes the frugal capitalists and makes their behavior a legally-binding template for all. It creates a global spendthrift trust and places all of society's wealth in it, making literal the Hobbesian metaphor of capital as a common pool. The wealthiest Americans cannot use capital for their personal pleasures. This removes the task of protecting society from the waste of its capital from the domain of fortuity and benevolence. It becomes a matter of the positive law.

\section{The End}

If we were to have started with the fiduciary conception of the property-tax bundle of rights, we could have ended up in a different world. The world of the absolute conception is our world, one of vast wealth and vast inequality, where private individuals have enormous power on account of their wealth and their absolute powers over it. The world of the fiduciary conception can be a world of great wealth and of great inequality, too, but it will have more equality in the consumption or lifestyle space. Property will have a different meaning, capital will not be absolutely owned. The rich will not be able to spend their great wealth on themselves. They can use it prudently not otherwise. They hold their excess capital in usufruct. They do not have all of the use-rights in property. They lack the jus abutendi. Society owns the capital, and has a general provision "requiring 
all things to be conserved in the public interest so far as not consumed in ordinary use."145 It is the tax system.

We can change at any time. We do not have to be passive observers to the tyrannical power of money in the present. We will leave to other days debates about the metaphysics, fairness, or anticipated empirical effects of moving -- reverting -- to a fiduciary conception of the property-tax bundle. The aim of this Article has been to show what this means and that it is possible. We can change, if we can change how we think about property, and tax, and property and tax combined. There is nothing necessary about the absolute property-tax conception. A simple subtraction of the right to waste and a simple change to the timing of tax gets us to a brave new world with echoes of a different past. We have a practicable way to provide that all wealth be held in usufruct for the living. We need only the will to make it so.

${ }^{145}$ Honore, supra note -. 